Shaftesbury, Anthony Ashley Cooper, 3d earl of An inquiry concerning virtue or merit

B

1386

15

1904 



\section{Englischa Sehulltatoder aus dam}

Debivie der Fhiosophia, Kuiturgoschichta und Natirwiscenschafit

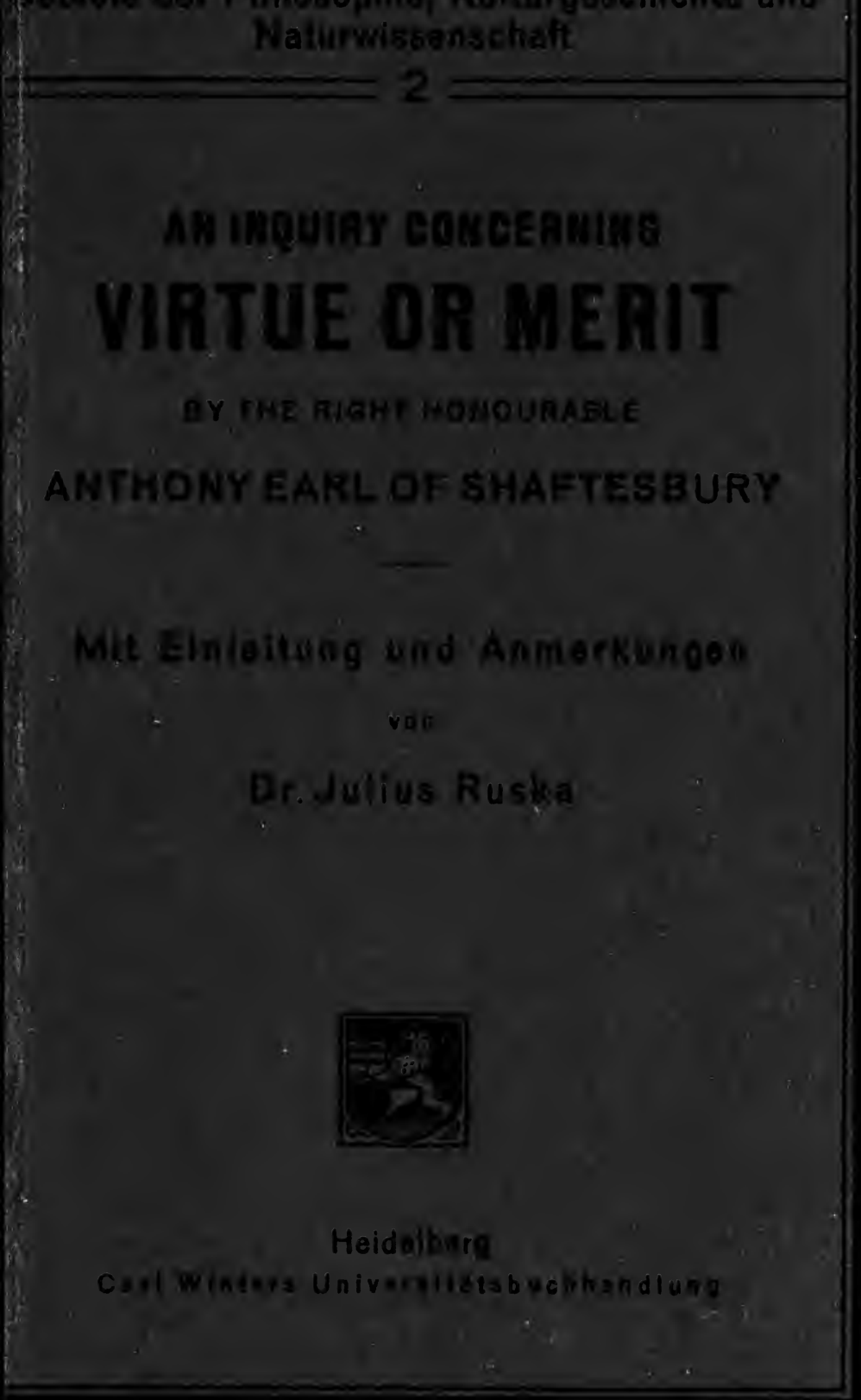




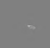

$s$ 
Englisehe Schriftsteller aus dem Gebiet der Philosophie, Kulturgeschichte und Naturwissenschaft.

2.

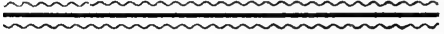

\section{AN INQUIRY CONCERNING}

\section{VIRTUE OR MERIT}

BY THE RIGHT HONOURABLE

Ashley Cooper

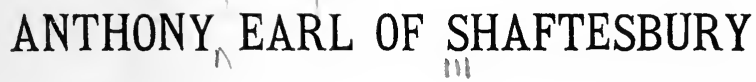

Mit Einleitung und Anmerkungen von

\section{Dr. Julius Ruska}

Professor an der Oberrealschule in Heidelberg

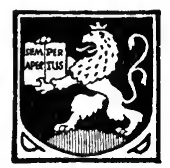

$* * * * * * *$ Heidelberg $1904 * * * * * * *$ Carl Winter's Universitätsbuehhandlung Vertreter für Österreich: Rudolf Lechner \& Sohn in Wien 


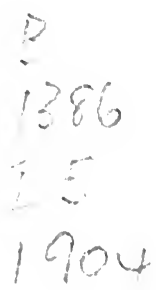

Alle Rechte, besonders das Recht der Übersetzung in fremde Sprachen, werden vorbehalten.

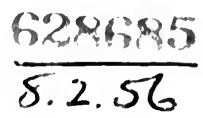




\section{In h a l t.}

Vorwort Seite

Leben und Schriften Shaftesburys. Grundlinien seiner philosophischen Anschauungen ......... 7

Gedankengang der "Untersuchung über Tugend oder Verdienst" ............. I2

AN INQUIRY CONCERNING VIRTUE OR MERIT.

Book I.

Part I. Section I.............. I5

"II ................. 2 . .

Part II. Section I............ 26

$)$ II ................. 33

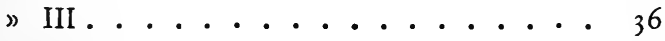

"IV.................... 42

Part III. Section I............ 45

》 II ................. so

»III.................. 54

Book II.

Part I. Section I. . . . . . . . 70

" III ............. 73

Part II. Section I. . . . . . . . 83

»II..................... 98

»III ........................ 108

Conclusion . . . . . . . . . . . II

Verzeichnis der Worterklärungen und sachlichen Anmerkungen ............... Ir6 
Digitized by the Internet Archive in 2007 with funding from Microsoft Corporation 


\section{Vorwort.}

Den auf die Grundlagen des Erkennens gerichteten Untersuchungen John Lockes folgt als zweiter Band dieser Sammlung Shaftesburys Untersuchung über die Grundlagen des sittlichen Handelns. Wie jener der Psychologie und Erkenntnistheorie neue Bahnen gewiesen hat, so steht dieser unter den Denkern, die der Ethik und Ästhetik ihre eigenen, von fremden Elementen freien Gesetze zu geben unternahmen, in erster Reihe.

$\mathrm{Zu}$ den bekanntesten Werken, in denen Shaftesbury eine seiner Bedeutung angemessene Behandlung erfahren hat, gehört Hettners Literaturgeschichte des achtzehnten Jahrhunderts (Bd. I, 5. Aufl. S. $172-187$ ). Für ein eingehenderes Studium unseres Autors sind aus der neueren Zeit die Monographien von G. Spicker "Die Philosophie des Grafen von Shaftesbury" (Freiburg I 872) und besonders G. v. Gižycki "Die Philosophie Shaftesburys» (Leipzig und Heidelberg 1876) zu nennen; in diesen Werken ist auch die ältere Literatur angeführt. Den Zusammenhang Shaftesburys mit den geistigen Strömungen des achtzehnten Jahrhunderts in England lernt man neben Hettners oder Windelbands Darstellung besonders noch durch Leslie Stephens "English thought in the eighteenth century" (London I88 I, 2 Bde.) kennen; den Einflub der englischen Philosophen auf die deutsche Philosophie des achtzehnten Jahrhunderts behandelt die Preisschrift von G. Zart (Berlin I88I).

Dem Text des "Inquiry concerning Virtue or Merit) ist die neue zweibändige Ausgabe der Characteristics von John M. Robertson (London I900) zugrunde gelegt; er hat nur im Part II des zweiten Buches erheblichere Kürzungen erfahren. Die Seitenzahlen von Zitaten aus andern Teilen der Characteristics beziehen sich auf diese Ausgabe. $\mathrm{Da}$ die Kàpiteleinteilung keine Andeutungen über den Inhalt gibt, schien es im Interesse des rascheren 
Zurechtfindens angezeigt, eine kurze Inhaltsangabe des "Inquiry» vorauszuschicken; im Text selbst sind die wichtigsten Ergebnisse durch Sperrdruck hervorgehoben. - Die Anmerkungen sollen nach den im Vorwort zu Band I der Sammlung ausgesprochenen Grundsätzen vor allem der sachlichen Klärung dienen, also das Verständnis der philosophischen Begriffswelt, ihres Gehaltes und ihrer Entwickelung durch Zurückgehen auf die Quellen fördern helfen. Wichtiger als das Gewand der Sprache ist uns ihr Inhalt, wichtiger als die Unbildung ihrer Laute und Wortformen ist ihre innere Geschichte, die Aufnahme neuer und Umbildung bereits vorhandener Begriffe und Gedanken. Rein sprachliche Bemerkungen kommen daher hier erst in zweiter Linie und mögen im übrigen dem Takt des Lehrers und den Bedürfnissen der Klasse anheimgestellt bleiben. Zur besseren Übersicht ist am Ende des Bändchens ein Verzeichnis der erklärten Wörter angefügt.

Hettner hat es beklagt ${ }^{1}$, daß die Gegenwart sich so wenig mit Shaftesburys Gedankenwelt beschäftige. Seit er die unten angeführten Worte schrieb, sind wieder nahezu fünfzig Jahre verflossen, und niemand, der sich mit dem Geiste von Shaftesburys Schriften vertraut gemacht hat, wird behaupten, dab der Ruf nach "mehr Shaftesbury" heute weniger Berechtigung hätte als damals. Vielleicht aber ist unsere Zeit mit ihrem gesteigerten Interesse für Kunst und geistige Kultur empfänglicher geworden für seine Art, die Dinge zu sehen, vielleicht sind wir heute besser vorbereitet, an den großen englischen Apostel reinen und freien Menschentums die Dankesschuld abzutragen, die noch nicht getilgt ist. Möge dieser Versuch, Shaftesbury in die Lektüre der Prima unserer neuhumanistischen Anstalten einzuführen, selbst als Beitrag hierfür angesehen werden und zugleich mithelfen, die Klagen über die Minderwertigkeit der Lektüre zum Schweigen zu bringen.

Heidelberg, im Juli 1904.

\section{J. Ruska.}

${ }^{1}$ Hettner, Literaturgesch. d. I8. Jahrhunderts. Bd. I, S. I72: "Shaftesbury ist eine der bedeutendsten Erscheinungen des achtzehnten Jahrhunderts. Die größten Geister dieses Zeitalters, nicht bloß die Engländer, sondern auch Leibniz, Voltaire, Diderot, Lessing, Mendelssohn, Wieland und Herder haben aus ihm die kräftigste Nahrung gezogen. Seine Reize sind ewig neu. Unsere Gegenwart tut sehr unrecht, ihn außer acht zu lassen.» 


\section{Leben und Schriften Shaftesburys. \\ Grundlinien seiner philosophischen An- schauungen.}

Anthony Ashley Cooper, nach dem Tode seines Vaters dritter Earl of Shaftesbury, wurde am 26. Februar 1671 zu London geboren. Sein Großvater, der bald nach diesem Ereignis zum Earl of Shaftesbury emporgestiegene Lord Ashley, übernahm, eifrig bestrebt, die Ehre und den Ruhm der Familie zu sichern, an Stelle des wenig dazu geeigneten Vaters vom Jahre 1674 ab die Sorge für den erstgeborenen Enkel, indem er dessen Erziehung in die Hände seines vertrauten Freundes John Locke legte. Dieser überwachte gewissenhaft die körperliche Entwickelung und die geistigen Fortschritte des ihm anvertrauten Knaben, während die eigentliche Unterweisung auf Lockes Empfehlung einer jungen Dame, Miss Elizabeth Birch, übertragen wurde. Sie hatte von ihrem Vater eine vorzügliche Erziehung und philologische Bildung erhalten und löste ihre Aufgabe, Master Anthony in die klassischen Sprachen einzuführen, aufs beste - er lernte Latein und Griechisch wie lebende Sprachen und hatte mit II Jahren schon eine vollkommene Fertigkeit in ihrem Gebrauch erlangt.

Nach dem Tode des Großvaters (1683) wurde auch das nahe Verhältnis zu Locke unterbrochen. Der Vater schickte den Sohn noch drei Jahre in die Winchester School, wo er viel unter dem gehässigen Verhalten seiner Mitschüler zu leiden hatte; hierauf brachte er mit einem Reisebegleiter einige Jahre hauptsächlich in Holland, Frankreich und Italien $z u$, eine für die Entwickelung der Welt- und Lebensanschauung des begabten Jünglings außerordentlich wichtige Zeit, während der er mit jenem jugendlichen Enthusiasmus, der aus allen seinen Schriften hervorleuchtet, seinen ausgesprochenen Neigungen für Literatur und Kunst nachzugehen Gelegenheit fand. Bald nach der Thronbesteigung Wilhelms von 
Oranien ( 1688 ) betrat auch er wieder den heimatlichen Boden und setzte seine philosophischen und literarischen Studien fünf Jahre lang fort, ehe er, 24 Jahre alt, seinen Sitz im Parlament einnahm (1695). Seine schwache Gesundheit nötigte ihn jedoch bald, die politische Laufbahn aufzugeben. Er lebte zu seiner Erholung nochmals ein Jahr hauptsächlich in Holland in regem Verkehr mit Le Clerc und Pierre Bayle ${ }^{1}$. Ende 1699 kehrte er wieder nach England zurück, wo er als Mitglied des Oberhauses nach dem Tod seines Vaters zwar wieder an den politischen Geschäften Anteil zu nehmen veranlabt wurde, aber infolge seines leidenden Zustandes vom Jahre 1703 an sich ganz ins Privatleben zurückzog. Jetzt erscheinen in rascher Folge die Schriften, denen Shaftesbury seinen Ruhm verdankt: im Jahre 1708 der "Letter concerning Enthusiasm", im Jahre I7o9 der "Essay on the Freedom of Wit and Humour" und "The Moralists", I 7 Io sein "Advice to an Author". Im Jahre I 7 I I endlich gab er seine Essays unter dem Titel "Characteristicks of Men, Manners, Opinions, Times etc." in drei Bänden aufs neue heraus, indem er die 1699 gegen seinen Willen durch Toland veröffentlichte Jugendarbeit "Inquiry Concerning Virtue or Merit" in überarbeiteter Form wieder veröffentlichte und einen Band "Miscellaneous Reflections on the preceding Treatises, and other Critical Subjects" hinzufügte. Nur noch zwei Jahre waren ihm nach dieser angeftrengten schriftstellerischen Tätigkeit vergönnt. Die zunehmenden Beschwerden seines asthmatischen Leidens veranlaßten ihn noch im Juli I7II, Linderung im Süden zu suchen. Er starb aber schon zu Anfang des Jahres I7I3, kaum 42 Jahre alt, in Neapel.

Hätte Shaftesbury, wie es nach den Traditionen des Hauses nahe genug lag, sich mehr an den politischen Kämpfen beteiligt und in den Gang der Staatsgeschäfte entscheidend eingegriffen, so würde die Darstellung seines äußeren Lebens eine größere Ausführlichkeit erfordern; Begabung und Neigung ließen ihn zum philosophischen Schriftsteller werden ${ }^{2}$, und so ist es der innere

${ }^{1}$ Hinsichtlich der zahlreichen Berührungspunkte von Shaftesbury mit Bayle vergleiche man die Charakteristik dieses Mannes in Windelb ands Geschichte der neueren Philosophie, Bd. I, S. 369-375 oder bei Hettner Bd. II, S. 43-48.

' Man denkt unwillkürlich an ihn selbst, wenn er in den Moralists seinen Philocles zu Palemon sagen läßt: "What mortal could imagine that a genius fitted for the greatest affairs, and formed amidst courts and camps, should have so violent a turn towards philosophy and the schools? Who is there could possibly 
Werdegang unseres Autors, der unser Interesse in erfter Linie in Anspruch nimmt, ist es Inhalt und Tendenz seiner Schriften, die uns vor allem beschäftigen müssen.

Den Geschmack an philosophischen Untersuchungen in den Kreisen der feinen Welt wieder $z u$ erwecken, ernstere, eines Mannes würdige Gegenstände an die Stelle fader oder frivoler Unterhaltung $\mathrm{zu}$ setzen, betrachtet Shaftesbury als seine besondere Aufgabe; wie man solche Fragen behandeln könne, ohne in steife Gelehrsamkeit und geistlose Pedanterie zu fallen, das will er durch seine eigene Darstellungskunst zeigen; mit lachenden Mund Wahrheiten zu sagen ${ }^{1}$, Aberglauben und Fanatismus, Vorurteile und Schwächen von Menschen und Zeiten durch die Waffen der Ironie und wenn nötig des Spottes zu bekämpfen, das durch finstere religiöse Vorstellungen verlorene Vertrauen auf die Güte der menschlichen Natur zu wecken und zu heben, für eine natürlichere Auffassung des menschlichen Pflichtenkreises zu wirken, Duldung und soziales Empfinden zu predigen, das Gefühl für die Schönheiten der Natur, für die Herrlichkeit der Welt wieder zu beleben, dies sind die wichtigsten Gegenstände, die Hauptziele seiner schriftstellerischen Tätigkeit. Es ist klar - mag in rein wissenschaftlichen Untersuchungen der Autor ganz hinter seinen Stoff zurück treten können - in Fragen der Ethik, der Religion, der literarischen Kritik muß der Schriftsteller zugleich ein Stück seiner selbst, seiner innersten Natur enthüllen, müssen die Werke zum Ausdruck der Persönlichkeit werden. Diese Durchdringung des Stoffs mit persönlichster Eigenart tritt uns aber gerade bei Shaftesbury in besonderem Maße entgegen; Form und Inhalt tragen einheitliches Gepräge, mag im einzelnen noch so viel fremden Quellen entstammen; wie ein Diamant das empfangene Licht in erhöhtem Glanze, in lebhafteren Farben zurückstrahlt, so leuchten und wärmen zugleich die geistigen Strahlen, die durch Kopf und Herz dieses begeisterten Kündigers der Humanität hindurchgegangen sind.

Wenn man die "Moralisten», in denen Shaftesbury die Form der platonischen Dialoge nachbildet, seine vollendetste Schrift

believe that one of your rank and credit in the fashionable world should be so thoroughly conversed in the learned one, and deeply interested in the affairs of a people so disagreeable to the generality of mankind and humour of the age?»)

1 Dies ist das Motto des Lelter concerning Enthusiasm: Ridentem dicere verum quid vetat... Horaz, Sat. I. 
genannt hat, so stellt $z$ weifellos schon sein Jugendwerk, die "Untersuchung über Tugend oder Verdienst», mit ihrer klaren Disposition und ihrem strengen Gedankenfortschritt den Kern seines philosophischen Standpunktes dar, um den sich die übrigen Abhandlungen wie freie Variationen und Erweiterungen desselben Themas gruppieren; jedem der fünf Treatises entspricht dann nach der Absicht des Autors als heiteres Nachspiel eine der Miscellaneous Reflections.

Natürliche Begabung und Regsamkeit des Geistes, ein glückliches Temperament, eine Umgebung, die der Entfaltung vorhandener Anlagen günstig war, eine sorgfältige, planmäbige Erziehung, die sie in gesunde und dem Höchsten zugewandte Bahnen zu lenken wußte - in vollkommenster Vereinigung haben diese Bedingungen bei dem Enkel Lord Ashleys zusammengewirkt, um den Grund zu seinen Erfolgen zu legen. Die Anfänge sind oben erwähnt; der Geist feinster weltmännischer Bildung umgab ihn von Jugend auf, der frühe und tiefe Einfluß der klassischen Literaturen verleugnet sich nirgends. In der Antike fand er die Vorbilder für seinen Kultus des Schönen - man hat ihn nicht mit Unrecht einen Platoniker genannt - , hier fand er den Satz, daB die Tugend in der Harmonie der natürlichen Kräfte bestehe, hier die Moralsysteme, die den Wert und Lohn der Tugend nicht im Jenseits suchen.

Es ist leicht zu sehen, daß Shaftesbury sich damit in einem schwer überbrückbaren Gegensatz zur christlichen Weltanschauung befand. Allein, was war wirkliches Christentum? Welche der historisch gewordenen Bekenntnisformen kam dem Geiste des Stifters am nächsten? Seit zwei Jahrhunderten hatte der dogmatische Zank der berufenen Interpreten des Christentums zu nichts geführt, als da $\triangle$ aus der Religion der Liebe eine Saat des Hasses und der Verfolgung aufgegangen war, daß sich die christlichen Völker gegenseitig zerfleischten, daß dem religiösen Fanatismus die unerhörtesten Menschenopfer gebracht wurden. Diese Zustände konnten nicht weiterdauern, wenn nicht alle Kultur in Frage gestellt und vernichtet werden sollte. Die besten Geister hatten sich von dem empörenden Schauspiel abgewandt, das die blutigen Religionsverfolgungen boten, die Stimmen, die gegenseitige Duldung forderten, wo eine Einigung nicht möglich war, erhoben sich inmer lauter, die Männer, welche zu einer Einigung über den Bekenntnissen zu gelangen strebten, indem sie Christentum und Gottesglauben philosophisch zu begründen unternahmen, gewannen immer größeren Einfluß. Jene Vernunft- und Gefühls- 
religion der englischen Deisten, die den Glauben an einen gütigen Schöpfer, an eine harmonisch vollkommene Weltordnung, an die Würde der menschlichen Natur gegenüber all dem Teufelsspuk und Hexenwahn wieder zur Geltung brachte, fand in Shaftesbury zwar nicht den ersten, wohl aber den begeistertsten und einflußreichsten Bekenner. Welcher Deutsche fühlte nicht, um nur wenige zu nennen, daß der Geist Lessings, Mendelssohns, Herders ihm hier entgegenweht, daf Schillers dithyrambische Jugenddichtung ganz aus diesem Enthusiasmus geboren ist; wie zahlreich und überraschend endlich sind trotz aller Gegensätze die Züge innerer Verwandtschaft mit Schleiermacher!

Mit einer gewissen logischen Notwendigkeit führt der Deismus zum Optimismus, zur Annahme, daß die wirkliche Welt zugleich die beste der möglichen Welten ist; es ist kein Zufall, $\mathrm{da}$ f fast gleichzeitig mit den "Moralisten» Leibniz seinen «Essai de Théodicée) veröffentlichte (Amsterdam I710), eine interessante Parallele zur Entdeckung der Infinitesimalrechnung, die durch Newton und Leibniz unabhängig $z u$ der Zeit erfolgte, als sie durch die Entwicklung der Mathematik gefordert war. Shaftesbury selbst aber ist - dies sei zum Schluß betont - ohne Zweifel nicht nur in diesem Punkte stark von Spinozas Ethik beeinflußt, die er vermutlich während seines zweiten Aufenthaltes in Holland kennen lernte. Er hat eine Reihe der wichtigsten Gedanken dieser tiefsinnigen Naturgeschichte der menschlichen Affekte direkt übernommen, wenn er auch das philosophische Fundament, auf dem sich Spinozas Sätze aufbauen, nicht in seine Betrachtungen einbezogen hat; auch hierin ein geistiger Organismus von höchster Lebenskraft, der assimiliert, was seiner Natur entspricht, und abstößt, was ihr fremd ist.

Es ist nicht Aufgabe dieser Einleitung, das Studium einer Geschichte der Literatur und Philosophie zu ersetzen. Wir unterlassen es daher, die Wirkung von Shaftesburys ethischen und ästhetischen Anschauungen auf die zeitgenössische und spätere Literatur, soweit sie nicht schon erwähnt worden ist, im einzelnen $\mathrm{zu}$ verfolgen. Wie sie auf heimischem Boden in Hutchesons (1694-1747) "Inquiry into the original of our ideas of beauty and virtues, in Henry Home und Edmund Burke ihre begeisterten Jünger und Fortbildner gefunden haben, so wurden sie besonders durch Voltaire nach Frankreich übertragen, so leben sie heute noch in unsern Klassikern fort, und vieles, was uns jetzt als selbstverständlich erscheint, hat direkt oder durch Vermittelung anderer Schriftsteller seine Wurzeln in Shaftesbury. 


\section{Gedankengang der "Untersuchung über Tugend oder Verdienst).}

Nach allgemeiner Ansicht sind Religion und Moral nicht voneinander zu trennen. Die tägliche Erfahrung lehrt aber, daß eifrige Religionsübung ohne echte Sittlichkeit, und wahre Sittlichkeit ohne das Bekenntnis zu einer bestimmten Religion, ja bei völligem Unglauben vorhanden sein können. Es ergibt sich hieraus die Aufgabe, zu untersuchen, was Tugend ist, und welche tatsächlichen Beziehungen $z$ wischen Tugend und Religion bestehen. Bei der außerordentlichen Verschiedenheit der religiösen Überzeugungen unter den Menschen ist aber erforderlich, eine Übersicht über ihre Hauptarten vorauszuschicken, damit die Wirkung einer jeden dieser Überzeugungen auf das sittliche Verhalten geprüft werden kann. -

Im Reich der Moral handelt es sich um die Begriffe des sittlich Guten und Bösen. Wir fragen daher zunächst: was nennen wir überhaupt gut und vollkommen, was nennen wir schlecht oder unvollkommen?

Wir können diese Bezeichnungen auf unzählige Dinge in der Natur nicht anwenden, weil uns die Einsicht in ihr Wesen und ihre Bestimmung abgeht. Wohl aber können wir bei dem Studium der lebenden Schöpfung (ähnlich wie bei Werken menschlicher Kunstfertigkeit) entdecken, daß jedes Geschöpf in sich selbst seinen Zweck trägt, und daß die Natur es zwingt, diese in ihm selbst liegenden Bedürfnisse mit allen seinen Kräften zu verfolgen. Ein Geschöpf gilt uns demnach für um so vollkommener, je besser es die von der Natur ihm gesetzten Zwecke zu erfüllen imstande ist, wie wir auch ein menschliches Werkzeug um so vollkommener nennen, je besser es den besonderen $Z$ wecken dient, für die es vom Menschen erfunden wurde.

Allein das einzelne Geschöpf ist sich nicht nur Selbstzweck, sondern es bildet mit den Geschöpfen seiner Art eine höhere Einheit mit neuen $Z$ wecken, die in dieser Gemeinschaft wurzeln; ja auch der Kreis der Geschöpfe gleicher 
Art ist wiederum undenkbar ohne die mannigfachsten Beziehungen zu Geschöpfen anderer Art, so daß wir zu immer umfassenderen Systemen mit immer verwickelteren Abhängigkeiten emporsteigen bis hinauf zur Gesamtheit der Geschöpfe dieser Erde, und weiter noch bis zu Planeten- und Weltsystemen. Und wieder werden wir in diesem erweiterten Zusammenhang ein Geschöpf um so vollkommener oder besser nennen, je mehr, und um so unvollkommener oder schlechter, je weniger es der Gesamtheit der natürlichen Zwecke zu entsprechen vermag.

Zum Begriff von Tugend und Verdienst gelangen wir aber erst beim Menschen, der den natürlichen Neigungen und Leidenschaften nicht blindlings folgt, sondern sie nach ihrer Bedeutung für den Einzelnen und die Gesellschaft zum Gegenstand seines Urteils, seiner Billigung und MiBbilligung macht. Wir nennen Gedanken und Handlungen verkehrt und böse, wenn sie aus unlauteren, dem Wohl des Ganzen widersprechenden Neigungen entspringen, recht und gut, wenn sie aus guten Neigungen hervorgehen. Tugend ist also ein fach das richtige Verhältnis zwischen den natürlichen Neigungen, die Harmonie $z$ wischen egoistischen und sozialen Antrieben.

Untersuchen wir nun, was die Tugend zu zerstören oder $z \mathrm{u}$ beeinträchtigen imstande ist, und was sie zu fördern und $z u$ befestigen vermag; und insbesondere, welchen schädlichen oder günstigen Einfluß die verschiedenen Meinungen über die Gottheit auf

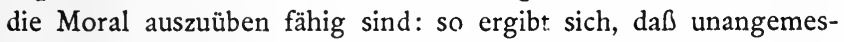
sene und unwürdige Vorstellungen von Gott ebenso große Gefahren für die Moralität mit sich bringen, als umgekehrt der Glaube an ein vollkommenstes Wesen, dem wir für unsere Handlungen verantwortlich sind, zur Stütze und Aufmunterung der Tugend dienen muB.

Es bleibt als zweiter Teil der Untersuchung die Frage: aus welchen Gründen sollen wir der Tugend nachstreben? Wenn die Tugend in der vollkommenen Harmonie der natürlichen Neigungen besteht, so ist sie damit zugleich der einzige Weg zum wahren Glück, ihr Mangel das größte Unglück. Vergleicht man aber die Gefühle von Freude und Glück, die einerseits aus körperlichen Ursachen, andererseits aus geistigen Quellen entspringen, so leuchtet ein, daß die geistigen Freuder ein höheres und edleres Glück verbürgen. Für das Glück des Menschen ist daher das von höchster Wichtigkeit, was eine ununterbrochene Kette von geistigen Freuden hervor- 
zubringen geeignet ist. Die geistigen Freuden entspringen aber im wesentlichen wieder den sozialen Neigungen und ihren mittelbaren Wirkungen, und es kommt daher zum Abschluß der Untersuchung nur noch darauf an, die folgenden Sätze zu beweisen und mit Beispielen zu belegen:

I. Da $\Omega$ die Stärke der auf das Wohl des Ganzen gerichteten natürlichen Neigungen das notwendige Erfordernis und einzige wahre Mittel zum persönlichen Glück ist, während ihr Mangel elend macht.

2. $\mathrm{Da} \_$die egoistischen Neigungen, wie Selbsterhaltungstrieb, Zorn, Habsucht, Ehrgeiz, Trägheit u. s. w., wenn sie den sozialen nicht untergeordnet werden, uns gleichfalls unglücklich machen.

3. Daß unnatürliche, weder dem Gemeinwohl noch dem Selbstinteresse dienende Neigungen, wie Grausamkeit, Neid, Menschenscheu u. s. w., den höchsten Grad des Unglücks herbeiführen. 


\title{
AN INQUIRY CONCERNING VIRTUE OR MERIT.
}

\section{BOOK I.}

\author{
PART I.
}

Section I.

Religion and Virtue $^{1}$ appear in many respects so nearly related, that they are generally presumed inse-

${ }^{1}$ Religion and virtue - anstatt diese beiden an die Spitze der Untersuchung gestellten Begriffskomplexe zu definieren, läßt Shaftesbury den Leser die Vorstellungen allmählich gewinnen, die er in seiner Schrift mit den Worten verknüpft. Es ist darauf zu achten, daß "Religion» hier in erster Linie das Bekenntnis zu bestimmten geschichtlich und dogmatisch festgelegten Glaubensgemeinschaften oder (Religionen» und die Teilnahme an ihren jeweiligen Mysterien und Kultformen, die «Religionsübung» bedeutet. Diesen mit dem Anspruch auf unmittelbare göttliche Offenbarung auftretenden positiven Religionen wird die "natürliche Religion» gegenübergestellt, die, aus Gefühlen des Staunens (we can admire nothing profoundly without a certain religious veneration II 177 ) und der Furcht vor den Naturgewalten entsprungen (primus in orbe deos fecit timor, die Furcht zuerst schuf auf dem Erdkreis Götter II 178), ebenfalls zur Erkenntnis und Verehrung göttlicher Mächte führt, in ihrer höchsten Form aber frei von allen Fesseln konfessioneller Dogmatik, jene "Vernunftreligion» darstellt, der (nach einem vielzitierten Wort des ersten Shaftesbury) alle weisen Männer angehören.

Der Begriff der "Tugend» hat durch die Einwirkung des christlichen Lebensideals, welches den Schwerpunkt des Menschen- 
parable companions. And so willing we are to believe well of their union, that we hardly allow it just to speak or even think of them apart. It may however be questioned whether the practice of the world in 5 this respect be answerable to our speculation'. 'Tis certain that we sometimes meet with instances which seem to make against this general supposition. We have known people who, having the appearance of great zeal ${ }^{2}$ in religion, have yet wanted even the comso mon affections of humanity ${ }^{3}$, and shown themselves extremely degenerate and corrupt. Others again, who have paid little regard to religion, and been considered as mere atheists ${ }^{4}$, have yet been observed to practise

daseins in ein künftiges Leben verlegte, einen andern Inhalt gewonnen, als er ursprünglich in der "virtus») der Römer oder der "arêtê" der Griechen enthalten ist. Denn virtus bedeutet zunächst nichts weiter als "Männlichkeit", wie iuventus "Jugend", senectus "Greisentum". Des Mannes wesentlichste Eigenschaft aber ist der Mut, die kriegerische Tüchtigkeit - genau das, was auch unser "Tugend" besagt. Indem der Begriff auf alles, was die Tauglichkeit zur Erfüllung der Pflichten gegen den Staat und die menschliche Gesellschaft einschließt, erweitert wird, vollzieht sich die Wendung zum Rechtlichen und Sittlichen, versteht man unter virtus "die der Natur und Vernunft entsprechende sittliche Gesinnung" (Cicero) und sucht ihr Wesen in der Harmonie der Seelenkräfte, im Maßhalten, im vernunftgemäßen Leben. Diesen antiken Auffassungen der Tugend steht auch Shaftesbury nahe.

${ }^{1}$ whether the practice of the world etc. "ob die Praxis der Welt in dieser Hinsicht unserer Theorie entsprichts; the practice v. griech. praktiké das Handeln, die Übung, das "wirkliche Verhalten", Gegensatz speculation (aus dem gr. theōria): das geistige Schauen, die wissenschaftliche "Betrachtung".

${ }^{2}$ zeal vom gr. zēlos "Eifer» mit besonderer Anwendung auf (übertriebenen) religiösen Eifer; zealot (gr. zēlōtés) der religiöse Fanatiker. In Letler concerning Enthusiasm und Miscellany II ein Hauptgegenstand der Betrachtung.

3 affections of humanily "Gefühle der Menschlichkeit».

- Shaftesbury denkt hier wohl an Männer wie Sokrates, der 
the rules of morality, and act in many cases with such good meaning and affection towards mankind as might seem to force an acknowledgment of their being virtuous. And in general, we find mere moral principles ${ }^{1}$ of such weight, that in our dealings with men s we are seldom satisfied by the fullest assurance given us of their zeal in religion, till we hear something further of their character ${ }^{2}$. If we are told a man is

als Gottesleugner und Jugendverderber zum Giftbecher verurteilt wurde, an Giordano Bruno, Hobbes, Spinoza. Die Übereinstimmung mit Bayles (1647-1705) Standpunkt fällt in die Augen; vgl. über ihn Windelband G. d. n. Ph. I 372: "Er wies mit historisch offenem Sinne bei jeder Gelegenheit darauf hin, wie herrliche sittliche Erscheinungen das Heidentum aufzuweisen und zu welchen Greueltaten auf der anderen Seite der christliche Fanatismus Veranlassung geboten habe; und dem Einwurfe, daß man für diese unsittlichen Auswüchse die Religion nicht verantwortlich machen dürfe, begegnet er mit dem schlagenden Worte, daß, wenn das sittlich Schlechte nicht ihre Frucht sei, man sie auch nicht für den Ursprung des sittlich Guten halten dürfe». - Atheist v. gr. ă-theos "Gottesleugner», wörtlich gott-los. Unser deutsches Wort zeigt deutlich, wie leicht sich an die Leugnung volkstümlicher Gottesvorstellungen der Makel moralischer Verworfenheit heftet. Denn nicht nur die absolute Leugnung alles Göttlichen, sondern schon jeder nicht nach den Vorstellungen der Massen oder der «Rechtgläubigen» geartete Gottesbegriff ruft die Beschuldigung des Atheismus und der sittlichen Verderbtheit wach.

1 moral principles "Grundsätze der Sittenlehre»; principles, das lat. principia, aus gr. archai übersetzt, bedeutet die "Anfänge», die letzten Ausgangspunkte des Denkens in Wissenschaft und Philosophie; moral, bei Cicero moralis, entspricht dem gr. ēthikós «sittlich». - Es sei hier schon mit allem Nachdruck darauf hingewiesen, daß die modernen Sprachen ihre ganze wissenschaftliche, philosophische, philologische u.s. w. Terminologie, auch wo sie in lateinischem Gewande erscheint, dem griechischen Geiste verdanken - except the blind forces of Nature, nothing moves in this world which is not Greek in its origin (Sir Henry S. Maine, nach Th. Gomperz, Griechische Denker).

2 character hier moral character, sittlicher Charakter.

Ruska, Authony Earl of Shaftesbury. 
religious, we still ask, "What are his morals"1? But if we hear at first, that he has honest ${ }^{2}$ moral principles, and is a man of natural justice and good temper ${ }^{3}$, we seldom think of the other question, "Whether he s be religious or devout?"

This has given occasion to inquire what honesty or virtue is, considered by itself, and in what manner it is influenced by religion; how far religion necessarily implies virtue $e^{4}$; and whether it be ro a true saying that it is impossible for an atheist to be virtuous, or share any real degree of honesty or merit.

And here it cannot justly be wondered at if the method of explaining things should appear somewhat unusual, since the subject matter ${ }^{5}$ has been so

1 his morals "seine Sitten», sein sittliches Verhalten.

2 honest "rühmlich»; daher honesty "ehrbares Verhalten»s.v.a. virtue. Bei Cicero ist honestum das sittlich Gute und Lobenswerte, das Wort ist von ihm als Ersatz des Griechischen tǒ kālón, eig. das Schöne, eingeführt. Die beiden Ausdrücke illustrieren zugleich den Unterschied zwischen römischer und griechischer Denkart.

${ }^{3}$ good temper "gute Mischung", freundlicher Charakter, gr. eukrāsî́a. Unser "Temperament», die lat. Übersetzung des gr. kräsis, bezeichnet zunächst die Blutmischung, genauer die Mischung der vier Hauptsäfte des Körpers, und beruht auf einer von Hippokrates $(460-377)$ und Galen $(13 \mathrm{I}-200)$ besonders ausgebildeten, bis ins 19. Jahrhundert lebenskräftig gebliebenen Theorie zur Erklärung der krankhaften Zustände des Körpers und des Gemüts. An andern Stellen spricht Shaftesbury von angry, fearful, amorous, easy, soft, sour, embittered, galled temper, von der Veränderlichleit des Temperaments und von intemperance.

4 "Kein Tropfen Moral kann der Religion beigemischt werden, ohne diese ihrer Reinheit zu berauben's ist Schleiermachers (wesentlich gegen Kant gerichtete) Antwort auf diese Frage.

s the subject matter "der vorliegende Stoff", der Gegenstand dieser Untersuchung. - Ein klassisches Beispiel, wie sich der konkrete Sinn eines Wortes nach seiner Aufnahme in die philosophische Sprache völlig verliert und auflöst. Materia (ebenso 
little examined, and is of so nice ${ }^{1}$ and dangerous speculation. For so much is the religious part of mankind alarmed by the freedom of some late pens ${ }^{2}$, and so great a jealousy is raised everywhere on this account, that whatever an author may suggest in favour s of religion, he will gain little credit in the cause if he allows the least advantage to any other principle ${ }^{3}$. On the other side, the men of wit and raillery ${ }^{4}$, whose pleasantest entertainment is in the exposing the weak sides of religion, are so desperately afraid of being to thrown into any serious thoughts of it, that they look

das zugrund liegende gr. hȳlē) bezeichnet ursprünglich Holz, insbesondere Bauholz; in der Folge wird das Wort zum Träger der Gegensätze von Stoff und Form, Körper und Geist, um endlich wieder im gemeinen Sprachgebrauch zur Bezeichnung irgend eines "Etwas» herabzusinken.

1 nice hier "schwierig, fein". Das Wort hängt mit lat. nescius "unwissend» zusammen und hat eigentümliche Bedeutungswandlungen erfahren.

2 some late pens "einige neuere Schriftsteller». Da die erste Veröffentlichung des Inquiry 1699 erfolgte, so liegt es nahe, an John Tolands (1670-1722) berühmte Schrift «Christianity not Mysterious) (1696) zu denken. Darauf weist auch der im folgenden gebrauchte Ausdruck free writer hin, der an den von Toland geprägten Begriff free thinker erinnert.

3 if he allows etc. - wenn er etwa wie Toland in Sachen der Religion die Vernunft an Stelle der Offenbarung setzt, oder zur Grundlegung der Moral noch andere als die vom religious part of mankind festgehaltenen Grundsätze und Ausgangspunkte als möglich anerkennt.

4 the men of wit and raillery "die Witzbolde und Spötter». Shaftesbury sagt sich im Folgenden mit aller Entschiedenheit von denen los, die mit frivolem Hohn auch das Heiligste verfolgen, wenngleich er selbst, besonders in seinem Essay " $O n$ the Freedom of Wit and Humours, die Anwendung von Ironie und Witz als Waffen zur Bekämpfung des Aberglaubens und Fanatismus empfohlen und verteidigt hatte, in der festen Überzeugung, da $\subseteq$ das Tüchtige und Lebensfähige gerade dadurch nur gewinnen könne. 
upon a man as guilty of foul play ${ }^{1}$ who assumes the air of a free writer, and at the same time preserves any regard for the principles of Natural Religion. They are apt to give as little quarter as they receive, and s are resolved to think as ill of the morals of their antagonists $^{2}$ as their antagonists can possibly think of theirs. Neither of them, it seems, will allow the least advantage to the other. It is as hard to persuade one sort that there is any virtue in religion, as the to other that there is any virtue out of the verge ${ }^{3}$ of their particular community. So that, between both, an author must pass his time ill who dares plead for religion and moral virtue without lessening the force of either, but allowing to each its proper is province and due rank, would hinder their being made enemies by detraction ${ }^{4}$.

However it be, if we would pretend to give the least new light, or explain anything effectually within the intended compass of this inquiry, it is necessary 2o to take things pretty deep, and endeavour by some short scheme $e^{5}$ to represent the original of each opinion, whether natural or unnatural, relating to the Deity. And if we can happily get clear of this thorny part of our philosophy ${ }^{6}$, the rest, it is hoped, may prove ; more plain and easy.

1 foul play "falsches Spiel», Unaufrichtigkeit, Unredlichkeit; Gegensatz fair play.

2 antagonists "Gegner", v. gr. ant-agōnistés Gegen-kämpfer, Widersacher.

s verge "Bereich, Bezirk, Umfang", ursprünglich vom Bereich der königlichen Gerichtsbarkeit, als deren Symbol ein Stab (verge, vom lat. virga Rute) dient.

4 detraction "Herabsetzung, Verunglimpfung".

"short scheme "kurzer Abriß, Übersicht), vom gr. schēma, Figur, Form.

"philosophy hier s. v. a. speculation, philosophische Betrachtung. 


\section{Section II.}

In the whole of things (or in the universe ${ }^{1}$ ) either all is according to a good order and the most agreeable to a general interest ${ }^{2}$, or there is that which is otherwise, and might possibly have s been better constituted, more wisely contrived, and with more advantage to the general interest of beings, or of the whole.

If every thing which exists be according to a good order, and for the best, then of ne-ro cessity there is no such thing as real ill in the universe, nothing ill with respect to the whole. ${ }^{3}$

Whatsoever then is so as that it could not really have been better, or any way better ordered, is perfectly good; whatsoever in the order of the world is can be called ill, must imply a possibility in the na-

1 the whole of things etc. der Inbegriff alles Seienden, das Weltganze, das "Weltall» oder Universum, ein besonders von den Stoikern gebrauchter Ausdruck.

- ${ }^{2}$ the most agreeable to a general interest "dem allgemieinen Besten so vollkommen wie möglich entsprechend». Gegen die Annahme einer nach den menschlichen Maßstäben des Nutzens, der Zweckmäßigkeit, der Schönheit von Gott geschaffenen Ordnung der Dinge wendet sich ausdrücklich Spin o za (1632-1677) in seiner Ethik (I, Anhang), wenngleich er aus dem Wesen Gottes ableitet, daß alle Dinge in höchster Vollkommenheit von Ewigkeit hervorgebracht sind (Ethik I, Satz 33, Anm. 2). Um so lebhafter ist bei Shaftesbury das Gefühl für die Schönheit der Welt entwickelt - the principle of beauty from whence in ancient languages the world itself (gr. kósmos, Schmuck) was named. Besonders vgl. man hierzu in den "Moralists" die Reden des Theokles.

- 3 Ähnlich Leibniz (I646-I716), der alles physische und moralische Übel nicht als wirklich gelten läßt, sondern aus der notwendigen Unvollkommenheit des Endlichen gegenüber dem Unendlichen, dem Universum, erklärt; vor der Harmonie des Ganzen als dem Abbild der göttlichen Vollkommenheit verschwinden die Mängel des Einzelnen. 
ture of the thing to have been better contrived or ordered. For if it could not, it is perfect, and as it should be.

Whatsoever is really ill, therefore, must be s caused or produced either by design (that is to say, with knowledge and intelligence), or, in defect of this, by hazard and mere chance.

If there be any thing ill in the universe from design, then that which disposes all things is no one 10 good designing principle ${ }^{1}$. For either the one designing principle is itself corrupt, or there is some other in being which operates contrarily and is ill.

If there be any ill in the universe from mere chance, then a designing principle or mind, whether good or is bad, cannot be the cause of all things. And consequently if there be supposed a designing principle, who is a cause only of good, but cannot prevent the ill, which happens from chance, or from a contrary ill design, then there can be supposed in reality no such 2o thing as a superior good design or mind, other than what is impotent and defective; for not to correct or totally exclude that ill of chance or of a contrary ill design, must proceed either from impotency or ill will.

25 Whatsoever is superior in any degree over the world, or rules in Nature with discernment ${ }^{2}$ and a mind, is what, by universal agreement, men call God. If there are several such superior minds, they are so many Gods; but if that single or

${ }^{1}$ good designing principle "mit Absicht wirkendes, gutes Prinzip der Welt", zwecksetzender intelligenter Urheber, schöpferischer Wille; weiter unten superior good design or mind.

${ }^{2}$ discernment wörtlich die Unterscheidung, die Fähigkeit zu unterscheiden, hier aber nichts anderes als der göttliche "Verstand". 
those several superiors are not in their nature necessarily good, they rather take the name of Daemon'. To believe therefore that everything is governed, ordered, or regulated for the best, by a designing principle or mind, necessarily good and permanent, is to s be a perfect Theist.

To believe nothing of a designing principle or mind, nor any cause, measure, or rule of things, but chance, so that in Nature neither the interest of the whole, nor of any particulars can be said to be in the least to designed, pursued or aimed at, is to be a perfect Atheist.

To believe no on e supreme designing principle or mind, but rather two, three or more (though in their nature good), is to be a Polytheist.

To believe the governing mind, or minds, not absolutely and necessarily good, nor confined to what is best, but capable of acting according to mere will or fancy ${ }^{2}$, is to be a Daemonist.

There are few, who think always consistently, or 20 according to one certain hypothesis ${ }^{3}$, upon any subject so abstruse and intricate as the cause of all things, and the economy or government of the universe ${ }^{4}$. For

1 Daemon, gr. daimōn, zunächst die "Gottheit», dann aber besonders die furchtbare, den Sterblichen Verderben bringende Gottheit, der "böse Geist), - so im Neuen Testament.

2 will or fancy "Willkür oder Laune»; fancy v. gr. phantasia Vorstellung, Bild einer Sache.

3 bypóthesis wörtlich "Unterstellung", Voraussetzung, grundlegende Annahme, besonders in wissenschaftlichen oder philosophischen Fragen. Vgl. z. B. S. 66, 69, 73.

4 economy or government of the universe "Weltplan oder Welt regierung»); economy ist das gr. oiko-nŏmía Verwaltung, Einrichtung, Betrieb, wörtlich "Haushalt», government geht durch das Lat. ebenfalls auf ein gr. Wort kybérnēsis «Steuerung» zurück. Der Begriff der Weltregierung, in dem Ausdruck der göttlichen 
'tis evident in the case of the most devout people, even by their confession, that there are times, when their faith ${ }^{1}$ hardly can support them in the belief of a supreme Wisdom, and that they are often tempted $s$ to judge disadvantageously of a providence and just administration in the whole.

That alone, therefore, is to be called a man's opinion, which is of any other the most habitual to him and occurs upon most occasions. So that 'tis hard to to pronounce certainly of any man that he is an atheist, because unless his whole thoughts are at all seasons and on all occasions steadily bent against all supposition or imagination of design in things, he is no perfect Atheist. In the same manner, if a man's thoughts is are not at all times steady and resolute against all imagination of chance, fortune, or ill design in things, he is no perfect Theist. But if any one believes more of chance and confusion than of design, he is to be esteemed more an Atheist than a Theist, from that 20 which most predominates or has the ascendant. And in case he believes more of the prevalency of an ill designing principle than of a good one, he is rather a Daemonist, and may be justly so called from the side to which the balance of his judgment most inclines. 25 All these sorts both of Daemonism, Polytheism, Atheism, and Theism may be mixed. ${ }^{2}$ Religion excludes only perfect atheism. Perfect daemonists

"Vorsehung» (providence, pro-videntia, bei den Stoikern prónoia) und "Verwaltung" (administration, das gr. dioíkēsis) enthalten, ist in erster Linie ein kirchlicher Lehrbegriff, dem die Vorstellung eines persönlichen, den Weltlauf bestimmenden Gottes zugrunde liegt.

1 faith "Glaube" als religiöse Überzeugung, religiöses $\mathrm{Be}$ kenntnis; vom lat. fides, eigentlich "Treue" und "Vertrauen".

${ }^{2}$ In einer Anmerkung stellt Shaftesbury die nach seiner Ansicht möglichen Mischungen zusammen. Man kann nicht be- 
undoubtedly there are in religion; because we know whole nations who worship a devil or fiend ${ }^{\mathbf{1}}$, to whom they sacrifice and offer prayers and supplications, in reality on no other account than because they fear him. And we know very well that, in some religions, there s are those who expressly give no other idea of God than of a being arbitrary, violent, causing ill and ordaining to misery; which in effect is the same as to substitute a daemon or devil in his room.

Now since there are these several opinions concern- ro ing a superior Power, and since there may be found perhaps some persons who have no formed opinion at all upon this subject; either through scepticism ${ }^{2}$, negligence of thought, or confusion of judgment; the consideration is, how any of these opinions, is or this want of any certain opinion, may possibly consist with virtue and merit, or be compatible with an honest or moral character.

haupten, daß dieser kahle und abstrakte Schematismus der bunten Mannigfaltigkeit und der geschichtlichen Bedeutung der verschiedenen Religionsformen gerecht wird. In solchen Dingen teilt Shaftesbury begreiflicherweise die Mängel seiner Zeit. Die Aufgabe einer vergleichenden Mythologie und Religionswissenschaft war noch nicht erfaßt, zu verständnisvollem, unbefangenem Eindringen in die Gedankenkreise entlegener Kulturen fehlten noch die wichtigsten Voraussetzungen. Bekanntlich hat David Hume (I7II bis 1776 ) in seiner "Natural History of Religion" und den "Dialogues concerning Natural Religions auf diesem Felde grundlegende Untersuchungen angestellt.

1 a devil or fiend - unser "Teufel" leitet sich sprachlich wie devil und diable (und ebenso der Iblîs im Koran) vom gr. diábolos d. h. "Verleumder» ab; zu fiend vgl. unsern Ausdruck "der böse Feind", eine Kombination von zwei andern biblischen Bezeichnungen des Satans.

2 scepticism vom gr. skĕ́psis "Untersuchung", kritische Prüfung überlieferter Lehrsätze, grundsätzlicher philosophischer Zweifel an Stelle blinden Glaubens. 


\section{PART II.}

\section{Section I.}

When we reflect on any ordinary frame or constitution either of Art or Nature ${ }^{1}$, and consider how $s$ hard it is to give the least account of a particular part without a competent knowledge of the whole, we need not wonder to find ourselves at a loss in many things relating to the constitution and frame of Nature herself. For to what end in Nature may things, even ro whole species of creatures, refer, or to what purpose they serve, will be hard for any one justly to determine; but to what end the many proportions and various shapes of parts in many creatures actually serve, we are able, by is the help of study and observation, to demonstrate with great exactness. ${ }^{2}$

1 Art or Nature - art ist hier Kunst im weitesten Sinn, jede Schöpfung des Menschen im Gegensatz zu den Produkten der Natur; Musik, Malerei u. s. w. heißen liberal arts.

${ }^{2}$ In diesen Sätzen präzisiert Shaftesbury seinen Standpunkt, indem er ebensosehr die populäre Erweiterung und den Mißbrauch des Zweckbegriffs ablehnt, als er gegenüber völliger Leugnung der Zwecke, wie bei Spinoza, die "Zweckmäßigkeit» in der organischen Natur und ihre wissenschaftliche Erkennbarkeit aufrecht hält. Die Frage nach den Endursachen (causae finales, vom gr. télos "Ende, Ziel, Zweck») birgt eines der ältesten und schwierig. sten Probleme der Philosophie. "Bei Sokrates ist noch alles, so wie es ist, für den menschlichen Nutzen geschaffen; bei Plato wird schon ein Selbstzweck der Dinge anerkannt, und ihre Zweckmäßigkeit wird dadurch eine mehr innerliche; bei Aristoteles fällt sogar der Zweck mit dem begrifflichen Wesen des Dinges vollständig zusammen” (F. A. Lange, Gesch. d. Mat. I902, I, I33). Aus dem Gebiet der unbelebten Natur sind heute die "Zwecke» durch die mechanische Naturerklärung völlig verdrängt; auch die biologischen Wissenschaften haben sich bei der Erklärung der L.ebensvorgänge immer mehr davon zu befreien gestrebt, ohne da $B$ es indessen gelungen wäre, das Geheimnis des Lebens auf 
We know ${ }^{1}$ that every creature has a private good and interest of his own ${ }^{2}$, which Nature has compelled him to seek, by all the advantages afforded him within the compass of his make. We know that there is in reality a right and a wrong state s of every creature, and that this right one is by nature forwarded and by himself affectionately sought. There being therefore in every creature a certain interest or good, there must be also a certain end to which everything in his constitution must naturally refer. To this ro end if anything, either in his appetites, passions, or affections, be not conducing but the contrary, we must of necessity own it ill to him. And in this manner he is ill with respect to himself, as he certainly is with respect to others of his kind, when any such appe- is tites or passions make him any way injurious to them. Now if by the natural constitution of any rational creature, the same irregularities of appetite which make him ill to others, make him ill also to himself, and if the same regularity of affections, which causes him to 20 be good in one sense, causes him to be good also in the other, then is that goodness by which he is

Formeln zu bringen oder das unmittelbare Gefühl und Bewuఏtsein zwecktätigen Handelns im Menschen in jeder Hinsicht als Illusion nachzuweisen; am wenigsten aber kann sich die Ethik der teleologischen Betrachtungsweise entschlagen.

1 Mit diesem Abschnitt vergleiche man Spinoza, Ethik IV, Anmerkung nach Satz XVIII: "Da die Vernunft nichts verlangt, was der Natur widerstrebt, so verlangt sie folglich selbst, da $\$$ jeder sich selbst liebe, seinen Nutzen, d. h. was ihm wahrhaft nützlich ist, suche, und alles, was den Menschen wahrhaft zu größerer Vollkommenheit führt, begehre; überhaupt, daß jedermann sein Sein, so gut er kann, zu erhalten strebe...) (Nach der Übers. v. J. Stern, Reclam).

2 a private good and interest of his own "ein besonderes Gut und persönliches Interesse»; dem gegenüber public good "Gemeinwohl» und general interest "Interesse der Gesamtheit». 
thus useful to others a real good and advantage to himself. And thus virtue and interest may be found at last to agree.

Of this we shall consider particularly in the latter s part of our inquiry. Our first design is to see if we can clearly determine what that quality is to which we give the name of goodness or virtue.

Should a historian ${ }^{1}$ or traveller describe to us a certain creature of a more solitary disposition than ever to was yet heard of; one who had neither mate nor fellow of any kind, nothing of his own likeness, towards which he stood well-affected or inclined, nor anything without or beyond himself for which he had the least passion or concern; we might be apt to say peris haps, without much hesitation, that this was doubtless a very melancholy creature ${ }^{2}$, and that in this unsociable and sullen state he was like to have a very disconsolate kind of life. But if we were assured that notwithstanding all appearances, the creature enjoyed 2o himself extremely, had a great relish of life, and was in nothing wanting to his own good, we might acknowledge, perhaps, that the creature was no monster ${ }^{3}$, nor absurdly constituted as to himself. But we should hardly, after all, be induced to say of him that he was is a good creature.

However, should it be urged against us that such as he was, the creature was still perfect in himself,

1 bistorian hier nicht Geschichtschreiber, sondern "Naturkundiger»; das gr. historìa bedeutet ganz allgemein jedes Erkunden und Wissen; daher natural bistory "Naturgeschichte».

${ }^{2}$ melancholy creature "trauriges Geschöpf»; melancholy wörtlich schwarzgallig, vom gr. melan-, schwarz und cholé, Galle; eines der vier 'Temperamente.

${ }^{3}$ monster "Ungeheuer"; vom lat. monstrum, etwas, worauf man (mit Abscheu) hinweist; von demselben Verbum, aber mit gerade entgegengesetztem Werturteil, stammt auch "Muster». 
and therefore to be esteemed good; for what had he to do with others? - in this sense, indeed, we might be forced to acknowledge that he was a good creature; if he could be understood to be absolute and complete in himself, without any real relation to s anything in the universe besides. - For should there be anywhere in Nature a system ${ }^{1}$ of which this living creature was to be considered as a part, then could he nowise be allowed good; whilst he plainly appeared to be such a part as made rather to the harm than so good of that system or whole in which he was included.

If therefore in the structure of this or any other animal, there be anything which points beyond himself, and by which he is plainly discovered to have is relation to some other being or nature besides his own, then will this animal undoubtedly be esteemed a part of some other system. For instance, if an animal has the proportions of a male, it shows he has relation to a female. And the respective proportions 20 both of the male and female will be allowed, doubtless, to have a joint relation to another existence and order of things beyond themselves. So that the creatures are both of them to be considered as parts of an other system, which is that of a particular race or 25 species of living creatures, who have some one common nature, or are provided for by some one order. or constitution of things subsisting together and cooperating towards their conservation and support.

In the same manner, if a whole species of animals 30 contribute to the existence or well-being of some other, than is that whole species, in general, a part only of some other system.

1 system, das gr. sýstēma, wörtlich "Zusammenstellung», planmäßige Anordnung und Gesamtheit von Dingen. 
For instance, to the existence of the spider that of the fly is absolutely necessary. The heedless flight, weak frame, and tender body of this latter insect, fits and determines him as much a prey as the rough make, s watchfulness, and cunning of the former fits him for rapine and the ensnaring part ${ }^{1}$. The web and wing are suited to each other. And in the structure of each of these animals there is as apparent and perfect a relation to the other as in our own bodies there is a so relation of limbs and organs; or as in the branches or leaves of a tree we see a relation of each to the other, and all, in common, to one root and trunk.

In the same manner are flies also necessary to the existence of other creatures, both fowls and fish. And is thus are other species or kinds subservient to one another, as being parts of a certain system, and included in one and the same order of beings.

So that there is a system of all animals: an animal-order or economy ${ }^{2}$, according to which the ani20 mal affairs are regulated and disposed.

Now, if the whole system of animals, together with that of vegetables, and all other things in this inferior world ${ }^{3}$, be properly comprehended in one system of a globe or earth, and if, again, this globe or earth 25 itself appears to have a real dependence on something still beyond, as, for example, either on its sun, the galaxy ${ }^{4}$ or its fellow-planets, then is it in reality a part

1 for the ensnaring part "für die Rolle des Überlistens»; to ensnare "in einer Schlinge fangen, verstricken»; snare Schnur.

2 economy Haushalt, "Verfassung".

3 this inferior world diese "untere» Welt, ein bei Shaftesbury natürlich nicht wörtlich zu nehmender Nachklang des alten Weltbildes, wonach der Himmel die Decke und die Erde den Boden des Universums bildet; zugleich einen Beigeschmack von Geringschätzung enthaltend.

"galaxy die "Milchstraße», das gr. galaxía, von găla Milch. 
only of some other system. And if it be allowed that there is in like manner a system of all things, and a universal nature, there can be no particular being or system which is not either good or ill in that general one of the universe; for if it be insigni- ; ficant and of no use, it is a fault or imperfection, and consequently ill in the general system.

Therefore if any being be wholly and really ill, it must be ill with respect to the universal system; and then the system of the universe is ill or imperfect. ro But if the ill of one private system be the good of others; if it makes still to the good of the general system (as when one creature lives by the destruction of another; one thing is generated from the corruption of another; or one planetary system or vortex may is swallow up another ${ }^{1}$ ), then is the ill of that private system no real ill in itself, any more than the pain of breeding teeth ${ }^{2}$ is ill in a system or body which is so constituted that, without this occasion of pain, it would suffer worse by being defective.

So that we cannot say of any being that it is wholly and absolutely ill, unless we can positively show and ascertain that what we call ill is nowhere good besides, in any other system, or with respect to any other order or economy whatsoever.

But were there in the world any entire species of animals destructive to every other, it may be justly called an ill species, as being ill in the animal system. And if in any species of animals (as in men,

1 planetary system or vortex ...; Anspielungen auf die Descartessche Wirbeltheorie (vortex Wirbel, Strudel), wonach die Materie im Weltraum sich in Wirbeln bewegt, deren jeder ein Sonnensystem bildet; die dunkel gewordenen Fixsterne, die von dem Wirbel aufgesogen sind, sind seine Planeten u. s. w. (Principia philosophiae I644).

${ }^{2}$ pain of breeding teeth "Schmerz beim Zahnen». 
for example) one man is of a nature pernicious to the rest, he is in this respect justly styled ${ }^{1}$ an ill man.

We do not, however, say of anyone that he is an ill man because he has the plague-spots ${ }^{2}$ upon him, s or because he has convulsive fits which make him strike and wound such as approach him. Nor do we say on the other side that he is a good man when, having his hands tied up, he is hindered from doing the mischief he designs; or (which is in a manner to the same) when he abstains from executing his ill purpose through a fear of some impending punishment, or through the allurement ${ }^{3}$ of some exterior reward.

So that in a sensible creature that which is not done through any affection ${ }^{4}$ at all makes neither good is nor ill in the nature of that creature, who then only is supposed good when the good or ill of the system to which he has relation is the immediate object of some passion or affection moving him.

20 Since it is therefore by affection merely that a creature is esteemed good or ill, natural or unnatural, our business will be to examine which are the good and natural, and which the ill and unnatural affections.

1 styled "bezeichnet"; geht auf gr.-lat. stylus Schreibschrift, Griffel zurück.

2 plague-spots "Pestmale, Pestbeulen»; plague "Plage» ursprünglich im Sinn von himmlischer Strafe, wie sie nach dem Alten Testament über Ägypten verhängt wurde; aus dem gr. plëgé "Schlag, Wunde» ins Lat. u. s. w. übergegangen.

3 allurement "Lockung, Anreiz".

" affection "Neigung", aus dem natürlichen Charakter entspringender innerer Antrieb zu einer Handlung; bald synonym mit passion "Leiden, Leidenschaft" (v. gr. păthos) gebraucht, bald ausdrücklich davon unterschieden: settled, sedate affection; sudden, strong passion. 


\section{Section II.}

In the first place, then, it may be observed that if there be an affection towards any subject considered as a private good, which is not really such, but imaginary, this affection, as being superfluous, and de-s tracting from the force of other requisite and good affections, is in itself vicious and ill, even in respect of the private interest or happiness of the creature.

If there can possibly be supposed in a creature such an affection towards self-good as is actually in its na- 1o tural degree, conducing to his private interest, and at the same time inconsistent with the public good, this may indeed be called still a vicious affection; and on this supposition a creature cannot really be good and natural in respect of his society or public, is without being ill and unnatural towards himself. But if the affection be then only injurious to the society when it is immoderate, and not so, when it is moderate, duly tempered, and allayed, then is the immoderate degree of the affection truly vicious, 20 but not the moderate. And thus, if there be found in any creature a more than ordinary self-concernment or regard to private good, which is inconsistent with the interest of the species or public, this must in every respect be esteemed an ill and vicious affection. And 2s this is what we commonly call selfishness, and disapprove so much in whatever creature we happen to discover it.

On the other side, if the affection towards private or self-good, however selfish it may be esteemed, is 30 in reality not only consistent with public good, but in some measure contributing to it; if it be such, perhaps, as for the good of the species in general every individual ought to share; 'tis so far from being ill or blamable in any sense, that it must be acknow-35

R uska, Anthony Earl of Shaftesbury. 
ledged absolutely necessary to constitute a creature good.

Thus the affection towards self-good may be a good affection or an ill one. For if this private affection 5 be too strong (as when the excessive love of life unfits a creature for any generous act) then it is undoubtedly vicious, and if vicious, the creature who is moved by it, is viciously moved, and can never be otherwise than vicious in some degree when moved by that affection. ro Therefore if through such an earnest and passionate love of life a creature be accidentally induced to do good (as he might be upon the same terms induced to do ill) he is no more a good creature for this good he executes than a man is the more an honest or good s man either for pleading a just cause, or fighting in a good one, for the sake merely of his fee or stipend.

Whatsoever therefore is done which happens to be advantageous to the species through an affection merely towards self-good, does not imply any more goodzo ness in the creature than as the affection itself is good. Let him, in any particular, act ever so well, if at the bottom it be that selfish action alone which moves him, he is in himself still vicious. Nor can any creature be considered otherwise when the ss passion towards self-good, though ever so moderate, is his real motive ${ }^{1}$ in the doing that to which a natural affection for his kind ought by right to have inclined him.

And indeed whatever exterior helps or secures an ;o ill-disposed creature may find to push him on towards the performance of any one good action, there can no goodness arise in him till his temper be so far changed that in the issue he comes in ear-

' motive "Beweggrund, Triebfeder". 
nest to be led by some immediate affection, directly and not accidentally, to good and against ill.

For instance, if one of those creatures supposed to be by nature tame, gentle, and favourable to mankind, be, contrary to his natural constitution, fierce, and sa- s vage, we instantly remark the breach of temper, and own the creature to be unnatural and corrupt. If at any time afterwards the same creature, by good fortune or right management comes to lose his fierceness, and is made tame, gentle, and treatable like other so creatures of his kind, 'tis acknowledged that the creature thus restored becomes good and natural. Suppose now that the creature has indeed a tame and gentle carriage, but that it proceeds only from the fear of his keeper, which, if set aside, his predominant passion in- is stantly breaks out; then is his gentleness not his real temper, but his true and genuine nature or natural temper remaining just as it was: the creature is still as ill as ever.

Nothing therefore being properly either goodness 20 or illness in a creature, except what is from natural temper, a good creature is such a one as by the natural temper or bent of his affections is carried primarily and immediately, and not secondarily and accidentally, to good 25 and against ill; and an ill creature is just the contrary.

When in general all the affections or passions are suited to the public good, or good of the species, as above mentioned, then is the natural temper entirely $3^{\circ}$ good. If, on contrary, any requisite passion be wanting, or if there be any one supernumerary or weak, or anywise disserviceable or contrary to that main end, then is the natural temper, and consequently the creature himself, in some measure corrupt and ill. 35 
There is no need of mentioning either envy, malice, frowardness ${ }^{1}$ or other such hateful passions, to show in what manner they are ill, and constitute an ill creature. But it may be necessary perhaps to s remark, that even as to kindness and love of the most natural sort (such as that of any creature for its offspring) if it be immoderate and beyond a certain degree, it is undoubtedly vicious. For thus over-great tenderness destroys the effect of love, and excessive so pity renders us incapable of giving succour. Hence the excess of motherly love is owned to be a vicious fondness; over-great pity, effeminacy and weakness; overgreat concern for self-preservation meanness and cowardice; too little, rashness; and none at all, or that which is is contrary (viz. a passion leading to self-destruction), a mad and desperate depravity.

\section{Section III.}

But to proceed from what is esteemed mere goodness, and lies within the reach and capacity of all zo sensible creatures, to that which is called virtue or merit, and is allowed to man only.

In a creature capable of forming general notions of things ${ }^{2}$, not only the outward beings which offer themselves to the sense are the 2 objects of the affection, but the very actions themselves, and the affections of pity, kindness, gratitude, and their contraries, being brought into the mind by reflection, become objects. So that, by means

"frowardness "Trotz, Widerspenstigkeit»; zu fro-ward vgl. to-ward bzw. un-toward.

${ }^{2}$ Dies ist die stoische Definition des Menschen; erst mit der Bildung der general notions, allgemeinen Begriffe, die etwa im 14. Lebensjahr einsetzt, kommt der Mensch auch geistig zur Reife. 
of this reflected sense ${ }^{1}$, there arises another kind of affection towards those very affections themselves, which have been already felt, and are now become the subject of a new liking or dislike.

The case is the same in the mental or moral sub- s jects as in the ordinary bodies or common subjects of sense. The shapes, motions, colours, and proportions of these latter being presented to our eye, there necessarily results a beauty or deformity, according to the different measure, arrangement, and disposition of ro their several parts. So in behaviour and actions, when presented to our understanding, there must be found, of necessity, an apparent difference, according to the regularity or irregularity of the subjects.

The mind, which is spectator or auditor of other is minds, cannot be without its eye and ear, so as to discern proportion, distinguish sound, and $\mathrm{scan}^{2}$ each sentiment or thought which comes before it. It can let nothing escape its censure. It feels the soft and harsh, the agreeable and disagreeable in the affections; 20 and finds a foul and fair, a harmonious and a dissonant, as really and truly here as in any musical numbers $^{3}$ or in the outward forms or representations of sensible things. Nor can it withhold its admiration and ecstasy ${ }^{4}$, its aversion and scorn, any more in what 25

1 by means of this reflected sense "mit Hülfe dieses inneren Sinnes»; reflection, die nach innen gerichtete Denktätigkeit im Gegensatz zur sensation, der unmittelbaren sinnlichen Empfindung.

2 scan "prüfen", von lat. scándere klettern; Schritt für Schritt aufsteigen, Punkt für Punkt durchprüfen, insbesondere das Metrum eines Gedichts feststellen, "skandieren".

3 musical numbers "musikalische Zahlenverhältnisse», von denen bekanntlich Wohlklang oder Harmonie (gr. harmonĭ́a Zusammenfügung, Übereinstimmung der Teile eines Ganzen) und Mißklang der Töne abhängen.

4 ecstasy "Begeisterung, Entzücken». Das gr. ékstasis be- 
relates to one than to the other of these subjects. So that to deny the common and natural sense of a sublime and beautiful in things, will appear an affectation merely, to any one s who considers duly of this affair.

Now as in the sensible ${ }^{1}$ kind of objects the species or images ${ }^{2}$ of bodies, colours, and sounds are perpetually moving before our eyes, and acting on our senses even when we sleep; so in the moral and intellectual so kind the forms and images of things are no less active and incumbent on the mind, at all seasons, and even when the real objects themselves are absent.

In these vagrant characters ${ }^{3}$ or pictures of manners, which the mind of necessity figures to itself and caris ries still about with it, the heart cannot possibly remain neutral; but constantly takes part one way or other. However false or corrupt it be within itself, it finds the difference, as to beauty and comeliness, between one heart and another, one turn of affection, 20 one behaviour, one sentiment and another; and accordingly, in all disinterested cases, must approve in some measure of what is natural and honest, and disapprove what is dishonest and corrupt.

Thus the several motions, inclinations, passions, is dispositions, and consequent carriage and behaviour of creatures in the various parts of life, being in several views or perspectives represented to the mind, which readily discerns the good and ill towards the

deutet wörtlich das "Herausstellen" aus dem normalen geistigen Zustand, den Wahnsinn; vgl. unser "entrückt» und "verrücktn.

1 sensible "sinnlich wahrnehmbar".

2 species or images "Arten oder Bilder", beides aus dem gr. eidos bezw. phántasma.

\& vagrant characters etc. "unstete, schwankende Vorstellungen oder Bildern; weiter unten representations. 
species or public, there arises a new trial or exercise of the heart, which must either rightly and soundly affect $^{1}$ what is just and right, and disaffect what is contrary, or corruptly affect what is ill and disaffect what is worthy and good.

And in this case alone it is we call any creature worthy or virtuous, when it can have the notion of a public interest, and can attain the speculation or science of what is morally good or ill, admirable or blamable, right or so wrong. For though we may vulgarly call an ill horse vicious, yet we never say of a good one, nor of any mere beast, idiot, or changeling ${ }^{2}$, though ever so good-natured, that he is worthy or virtuous.

So that if a creature be generous, kind, constant, is compassionate, yet if he cannot reflect on what he himself does, or sees others do, so as to take notice of what is worthy or honest, and make that notice or conception of worth and honesty to be an object of his affection, he has not the character 20 of being virtuous; for thus, and no otherwise, he is capable of having a sense of right or wrong, a sentiment or judgment of what is done through just, equal, and good affection, or the contrary.

Whatsoever is done through any unequal affection 2s is iniquitous, wicked, and wrong. If the affection be equal, sound, and good, and the subject of the affection such as may with advantage to society be ever in the same manner prosecuted or affected, this must necessarily constitute what we call equity and right 30 in any action. For wrong is not such action as is barely the cause of harm (since at this rate

1 affect "erstreben, lieben», disaffect "verabscheuen, hassen».

2 idiot or changeling "Narr oder Wechselbalg"; gr. idiōtēs urspr. Privatmann, Laie, der nicht wissenschaftlich gebildet ist. 
a dutiful son arming at any enemy, but by mistake or ill chance happening to kill his father, would do a wrong), but when anything is done through insufficient or unequal affection (as when a son shows no $s$ concern for the safety of a father; or, where there is need of succour, prefers an indifferent person to him) this is of the nature of wrong.

Neither can any weakness or imperfection in the senses be the occasion of iniquity or so wrong; if the object of the mind itself be not at any time absurdly framed, nor any way improper, but suitable, just, and worthy of the opinion and affection applied to it. For if we will suppose a man who, being sound and entire both in his reason and affecs tion, has nevertheless so depraved a constitution or frame of body that the natural objects are, through his organs of sense, as through ill glasses, falsely conveyed and misrepresented, 'twill be soon observed, in such a person's case, that since his failure is not in 20 his principal or leading part, he cannot in himself be esteemed iniquitous or unjust.

It is otherwise in what relates to opinion, belief, or speculation. For whatsoever causes a misconception or misapprehension of the worth or is value of an object, so as to diminish a due, or raise any undue, irregular or unsocial affection, must necessarily be the occasion of wrong. Thus he who affects or loves a man for the sake of something which is reputed honourable, but which is in reality vicious, is 3o himself vicious and ill. The beginnings of this corruption may be noted in many occurrencies; as when an ambitious man, by the fame of his high attempts, a conqueror or a pirate ${ }^{1}$ by his boasted enterprises,

'pirate "Seeräuber"; vom gr. peiratés. Die Bedeutung des Stammwortes ist "versuchen, unternehmen, auskundschaften", der ursprüngliche Sinn also wohl "Abenteurer». 
raises in another person an esteem and admiration of that immoral and inhuman character which deserves abhorrence, 'tis then that the hearer becomes corrupt, when he secretly approves the ill he hears. But on the other side, the man who loves and esteems another, s as believing him to have that virtue which he has not, but only counterfeits, is not on this account either vicious or corrupt.

A mistake therefore, in fact, being no cause or sign of ill affection, can be no cause of vice. But a ro mistake of right being the cause of unequal affection, must of necessity be the cause of vicious action in every intelligent or rational being.

But as there are many occasions where the matter of right may even to the most discerning part of man- is kind appear difficult, and of doubtful decision, 'tis not a slight mistake of this kind which can destroy the character of a virtuous or worthy man. But when, either through superstition or ill custom, there come to be very cross mistakes in the assignment or 20 application of the affection; when the mistakes are either in their nature so cross, or so complicated and frequent, that a creature cannot well live in a natural state nor with due affections, compatible with human society and civil life; then is the character of virtue 25 forfeited.

And thus we find how far worth and virtue depend on a knowledge of right and wrong and on a use of reason, sufficient to secure a right application of the affections; that nothing 30 horrid or unnatural, nothing unexemplary, nothing destructive of that natural affection by which the species or society is upheld, may on any account, or through any principle or notion of honour or religion, be at any time affected or prosecuted as a 35 
good and proper object of esteem. For such a principle as this must be wholly vicious; and whatsoever is acted upon it can be no other than vice and immorality. And thus if there be anything which teaches $s$ men either treachery, ingratitude, or cruelty, by divine warrant $^{1}$ or under colour ${ }^{2}$ and pretence of any present or future good to mankind; if there be anything which teaches men to persecute their friends through love, or to torment captives of war in sport, or to offer human to sacrifice, or to torment, macerate, or mangle themselves in a religious zeal, before their God, or to commit any sort of barbarity or brutality as aimable or becoming; be it custom which gives applause, or religion which gives a sanction ${ }^{3}$; this is not, nor ever is can be, virtue of any kind, or in any sense, but must remain still horrid depravity, notwithstanding any fashion, law, custom or religion which may be ill and vicious itself, but can never alter the eternal measures and immutable independent 20 nature of worth and virtue.

\section{Section IV.}

Upon the whole. As to those creatures who are only capable of being moved by sensible objects, they are accordingly good or vicious as the sensible affec25 tions stand with them. It is otherwise in creatures capable of framing rational objects of moral good. For in one of this kind, should the sensible affections stand ever so much amiss, yet if they prevail not,

1 warranl "Vollmacht"; vgl. "Garantie".

2 under colour "unter dem Vorwand»; eigentlich "unter der Flagge».

3 Diese scharfe Kritik richtet sich, wie andere Stellen zeigen, sowohl gegen die im Alten Testament erzählten Geschichten als auch gegen die christlichen Scheiterhaufen. 
because of those other rational affections spoken of, 'tis evident the temper still holds good in the main, and the person is with justice esteemed virtuous by all men.

More than this. If by temper anyone is passionate, s angry, fearful, amorous, yet resists these passions, and notwithstanding the force of their impression adheres to virtue, we say commonly in this case that the virtue is the greater; and we say well. Though if that which restrains the person and holds so him to a virtuous-like behaviour be no affection towards goodness or virtue itself, but towards private good merely, he is not in reality the more virtuous as has been shown before. But this still is evident, that if voluntarily and without foreign constraint an is angry temper bears, or an amorous one refrains, so that neither any cruel nor immodest ${ }^{1}$ action can be forced from such a person, though ever so strongly tempted by his constitution, we applaud his virtue above what we should naturally do if he were free of 20 this temptation and these propensities. At the same time, there is nobody (that) will say that a propensity to vice can be an ingredient ${ }^{2}$ in virtue, or any way necessary to complete a virtuous character.

There seems therefore to be some kind of difficulty ${ }_{25}$ in the case, but it amounts only to this. If there be any part of the temper in which ill passions or affections are seated, whilst in another part the affections towards moral good are such as absolutely to master those attempts of their antagonists, this is the greatest ${ }_{30}$

1 immodest (unsittlich», wörtlich "unmäßjig» - geht auf die Anschauung zurück, daß die Tugend im Maßhalten (modus, modestia), in der richtigen Mitte zwischen dem Zuviel und Zuwenig der Begierden besteht.

2 ingredient "Bestandteil», Teilinhalt. 
prove imaginable that a strong principle of virtue ${ }^{1}$ lies at the bottom and has possessed itself of the natural temper. Whereas if there be no ill passions stirring, a person may be indeed more cheaply virtuous, that $s$ is to say, he may conform himself to the known rules of virtue without sharing so much of a virtuous principle as another. Yet if that other person, who has the principle of virtue so strongly implanted, comes at last to lose those contrary impediments supposo sed in him, he certainly loses nothing in virtue; but on the contrary, losing only what is vicious in his temper, is left more entire to virtue, and possesses it in a higher degree.

Thus is virtue shared in different degrees by rais tional creatures, such at least as are called rational, but who come short of that sound and well-established reason which alone can constitute a just affection, a uniform and steady will and resolution. And thus vice and virtue are found variously mixed, 20 and alternately prevalent in the several characters of mankind. For it seems evident from our inquiry, that how ill soever the temper or passions may stand with respect either to the sensible or the moral objects; however passionate, furious, or cruel zs any creature may become; however vicious the mind be, or whatever ill rules or principles it goes by; yet if there be any flexibleness or favourable inclination towards the least moral object, the least appearance of moral good (as if there be any such thing as kindness, 30 gratitude, bounty, or compassion), there is still some-

1 a slrong principle of virtue "ein starker Antrieb zur Tugend"; frinciple alles Anfängliche, also hier etwa "ursprüngliche Kraft», wie in der Chemie "Urstoff" oder Element, in der Sphäre des Denkens "Grundsatz", in der des Handelns "Beweggrund, Triebfedern. 
thing of virtue left, and the creature is not wholly vicious and unnatural.

Thus a ruffian ${ }^{1}$ who out of a sense of fidelity and honour of any kind refuses to discover his associates, and rather than betray them is content to endure s torments and death, has certainly some principle of virtue, however he may misapply it. 'Twas the same case with that malefactor who, rather than do the office of executioner to his companions, chose to keep them company in their execution.

In short, as it seems hard to pronounce of any man that he is absolutely an atheist, so it appears altogether as hard to pronounce of a man that he is absolutely corrupt or vicious, there being few, even of the horridest villains ${ }^{2}$, who have not something of is virtue in this imperfect sense. Nothing is more just than a known saying, that it is as hard to find a man wholly ill as wholly good, because wherever there is any good affection left, there is certainly some goodness or virtue still in being. And having considered 20 thus of virtue, what it is in itself, we may now consider how it stands with respect to the opinions concerning a Deity, as above mentioned.

\section{PART III.}

\section{Section I.}

The nature of virtue consisting (as has been explained) in a certain just disposition or proportionable affection of a rational creature towards the moral ob-

1 ruffian Räuber, Wegelagerer, vom ital. ruffiano.

2 villain "Schurke», Auswurf der Menschheit. Das lat. villanus bezeichnet ursprünglich den zum Landhaus (villa) gehörigen Sklaven, der die Feldarbeit zu besorgen hat. Der Bedeutungswandel vollzieht sich in derselben absteigenden Richtung wie bei knave, idiot u. s. w. 
jects of right and wrong, nothing can possibly in such a creature exclude a principle of virtue, or render it ineffectual, except what

I. Either takes away the natural and just sense of s right and wrong;

2. Or creates a wrong sense of it;

3. Or causes the right sense to be opposed by contrary affections.

On the other side, nothing can assist or advance to the principle of virtue except what either in some manner nourishes or promotes a sense of right and wrong, or preserves it genuine and uncorrupt, or causes it when such to be obeyed, by subduing and subjecting the other affections to it.

is We are to consider, therefore, how any of the above mentioned opinions on the subject of a Deity may influence in this cases, or produce either of these three effects.

As to the first case, the taking away the na20 tural sense of right and wrong.

It will not surely be understood that by this is meant the taking away the notion of what is good or ill in the species or society. For of the reality of such a good and ill, no rational creature can as possibly be insensible. Every one discerns and owns a public interest, and is conscious of what affects his fellowship or community. When we say, therefore, of a creature that he has wholly lost the sense of right and wrong ${ }^{1}$, we suppose that being able to discern 30 the good and ill of his species, he has at the same time no concern for either, nor any sense of excel-

'sense of right and wrong "Gefühl, Sinn" für Recht und Unrecht. Shaftesbury sieht in diesem natürlichen Gefühl, das er auch als moral sense und anticipating fancy bezeichnet, den Urquell des sittlichen Verhaltens. Vgl. S. 49, 55, 66. 
lency or baseness in any moral action relating to the one or to the other. So that except merely with respect to a private and narrowly confined self-good, 'tis supposed there is in such a creature no liking or dislike of manners; no admiration or love of anything as s morally good, nor hatred of anything as morally ill, be it ever so unnatural or deformed.

There is in reality no rational creature whatsoever who knows not that when he voluntarily offends or does harm to anyone, he cannot fail to create an ap- to prehension and fear of like harm, and consequently a resentment and animosity in every creature who observes him. So that the offender must needs be conscious of being liable to such treatment from every one as if he had in some degree offended all.

Thus offence and injury are always known as punishable by every one; and equal behaviour (which is therefore called merit) is rewardable and well-deserving from every one. Of this even the wickedest creature living must have a sense. So that if 20 there be any further meaning in this sense of right and wrong; if in reality there be any sense of this kind which an absolute wicked creature has not; it must consist in a real antipathy ${ }^{1}$ or aversion to injustice or wrong, and in a real affection or love towards 25 equity and right for its own sake, and on the account of its own natural beauty and worth.

It is possible to suppose a mere sensible creature originally so ill-constituted and unnatural as that, from the moment he comes to be tried by sensible objects, 30 he. should have no one good passion towards his kind, no foundation either of pity, love, kindness, or social affection. It is full as impossible to conceive that

1 antipathy "Wider-willen, Abneigung», wie sympathy "Mitleiden, Mitgefühl, Zuneigung», vom gr. păthos Leiden u. s. w. 
a rational creature coming first to be tried by rational objects, and receiving into his mind the images or representations of justice, generosity, gratitude, or other virtue, should have no liking of these or dislike of s their contraries, but be found absolutely indifferent towards whatsoever is presented to him of this sort. A soul, indeed, may as well be without sense as without admiration ${ }^{1}$ in, the things of which it has any knowledge. Coming therefore to a so capacity of seeing and admiring in this new way, it must needs find a beauty and a difformity as well in actions, minds, and tempers, as in figures, sounds, or colours. If there be no real amiableness or deformity in moral acts, there is at least an imaginary one of is full force. Though perhaps the thing itself should not be allowed in Nature, the imagination or fancy of it must be allowed to be from Nature alone. Nor can anything besides art and strong endeavour, with long practice and meditation, overcome such a natural pre20 vention or prepossession of the mind in favour of this moral distinction.

Sense of right and wrong therefore being as natural to us as natural affection itself, and being a first principle in our constitution and make, there 25 is no speculative opinion, persuasion, or belief, which is capable immediately or directly to exclude or destroy it. That which is of original and pure nature, nothing beside contrary habit and custom (a second nature) is able to displace. And 30 this affection being an original one of earliest rise in the soul or affectionate part, nothing beside contrary affection, by frequent check and control, can operate

"admiration - daß alle Philosophie mit dem "Verwundern" und "Ërstaunen" anfängt, bemerken schon Platon und Aristoteles. 
upon it, so as either to diminish it in part or destroy it in the whole. ${ }^{1}$

It is evident in what relates to the frame and order of our bodies, that no particular odd mien or gesture, which is either natural to us and consequent to our s make, or accidental and by habit acquired, can possibly be overcome by our immediate disapprobation, or the contrary bent of our will ever so strongly set against it. Such a change cannot be effected without extraordinary means, and the intervention of art and method, ro a strict attention, and repeated check. And even thus, Nature we find is hardly mastered, but lies sullen, and ready to revolt on the first occasion. Much more is this the mind's case in respect of that natural affection and anticipating fancy which makes the sense is of right and wrong. 'Tis impossible that this can instantly, or without much force and violence, be effaced, or struck out of the natural temper, even by means of the most extravagant belief or opinion in the world.

Neither Theism therefore nor Atheism nor Daemonism nor any religious or irreligious belief of any kind being able to operate immediately or directly in this case, but indirectly by the intervention of opposite or of favourable affections casually 25 excited by any such belief, we may consider of this effect in our last case, where we come to examine the agreement or disagreement of other affections with this natural and moral one which relates to right and wrong.

1 Zu diesem Satz vgl. Spinoza Ethik IV, 7: «Ein Affekt kann nicht anders gehemmt oder aufgehoben werden als durch einen andern, entgegengesetzten und stärkeren Affekt». 


\section{Section II.}

As to the second case, viz. the wrong sense or false imagination of right and wrong.

This can proceed only from the force of custom $s$ and education in opposition to Nature, as may be noted in those countries where, according to custom or politic institution, certain actions naturally foul and odious are repeatedly viewed with applause, and honour ascribed to them. For thus 'tis possible that a man, to forcing himself, may eat the flesh of his enemies, not only against his stomach, but against his nature, and think it nevertheless both right and honourable as supposing it to be of considerable service to his community, and capable of advancing the name and spreading is the terror of his nation.

But to speak of the opinions relating to a Deity, and what effect they may have in this place. As to the atheism, it does not seem that it can directly have any effect at all towards the setting up a zo false species of right or wrong. For notwithstanding a man may through custom, or by licentiousness of practice, favoured by atheism, come in time to lose much of his natural moral sense, yet it does not seem, that atheism should of itself be the cause of any estimation 25 or valuing of anything as fair, noble, and deserving, which was the contrary. It can never, for instance, make it be thought that the being able to eat man's flesh, or commit bestiality, is good and excellent in itself. But this is certain, that by means of corrupt religion 30 or superstition, many things the most horridly unnatural and inhuman come to be received as excellent, good, and laudable in themselves.

Nor is this a wonder. For wherever anything, in its nature odious and abominable, is by religion ad35 vanced as the supposed will or pleasure of a supreme 
Deity, if in the eye of the believer it appears not indeed in any respect the less ill or odious on this account, then must the Deity of necessity bear the blame. and be considered as a being naturally ill and odious, however courted and sollicited through mistrust and s fear. But this is what religion, in the main, forbids us to imagine. It everywhere prescribes esteem and honour in company with worship and adoration. Whensoever therefore it teaches the love and admiration of a Deity who has any apparent character of ill, it teaches to at the same time a love and admiration of that ill, and causes that to be taken for good and amiable which is in itself horrid and detestable.

For instance, if Jupiter be he who is adored and reverenced, and if his history represents him amorous- is ly inclined, and permitting his desires of this kind to wander in the loosest manner, 'tis certain that his worshippers, believing this history to be literally and strictly true, must of course be taught a greater love of amorous and wanton acts. If there be a religion ${ }^{120}$ which teaches the adoration and love of a God whose character it is to be captious and of high resentment, subject to wrath and anger, furious, revengeful, and revenging himself when offended, on others than those who gave offence; and if there be added to the cha- 25 racter of this God of fraudulent disposition, encouraging deceit and treachery amongst $\mathrm{men}^{2}$, favourable to

${ }^{1}$ Mit dem folgenden meint Shaftesbury das Judentum; die im Einzelnen gegen die Unvollkommenheiten der alttestamentlichen Gottesvorstellung gemachten Vorwürfe lassen sich leicht belegen.

2 Vgl. die Geschichte Jakobs und Esaus, Abrahams, den Auszug aus Ägypten und zahllose andere Geschichten im Alten Testament - alles dies ebenfalls unter der Voraussetzung to be literally and strictly true. 
a few, though for slight causes, and cruel to the rest, 'tis evident that such a religion as this being strongly enforced must of necessity raise even an approbation and respect towards the vices of this kind and breed s a suitable disposition, a capricious, partial, revengeful, and deceitful temper. For even irregularities and enormities of an heinous kind must in many cases appear illustrious to one who considers them in a being admired and contemplated with the highest honour and so veneration.

If in following the precepts of his supposed God, or doing what he esteems necessary towards the satisfying of such his Deity, the worshipper is compelled only by fear, and, contrary to his inclination, performs is an act which he secretly detests as barbarous and unnatural, then has he an apprehension or sense still of right and wrong, and, according to what has been already observed, is sensible of ill in the character of his God, however cautious he may be of 20 pronouncing anything of this subject, or so thinking of it as to frame any formal or direct opinion in the case. But if by insensible degrees, as he proceeds in his religious faith and devout exercise, he comes to be more and more reconciled to the malignity, arbitrarias ness, partiality, or revengefulness of his believed Deity, his reconciliation with these qualities themselves will soon grow in proposition, and the most cruel, unjust, and barbarous acts will, by the power of this example, be often considered by him not only as just and 3o lawful, but as divine and worthy of imitation.

For whoever thinks there is a God, and pretends formally to believe that he is just and good, must suppose that there is independently such a thing as justice and injustice, truth ss and falsehood, right and wrong, according to 
which he pronounces that God is just, righteous, and true. If the mere will, decree, or law of God be said absolutely to constitute right and wrong, then are these latter words of no significancy at all. For thus, if each part of a contradiction were s affirmed for truth by the Supreme Power, they would consequently become true. Thus if one person were decreed to suffer for another's fault, the sentence would be just and equitable. And thus, in the same manner, if arbitrarily and without reason, some beings were ro destined to endure perpetual ill, and others as constantly to enjoy good, this also would pass under the same denomination. But to say of anything that it is just or unjust on such a foundation as this, is to say nothing, or to speak without a meaning.

And thus it appears that where a real devotion and hearty worship is payed to a Supreme Being, who in his history or character is represented otherwise than as really and truly just and good, there must ensue a loss of rectitude, a disturbance of thought, and a cor- 20 ruption of temper and manners in the believer. His honesty will of necessity be supplanted by his zeal, whilst he is thus unnaturally influenced, and rendered thus immorally devout.

To this we need only add, that as the ill character is of a God does injury to the affections of men, and disturbs and impairs the natural sense of right and wrong, so, on the other hand, nothing can more highly contribute to the fixing of right apprehensions, and a sound judgment or sense of 30 right and wrong, than to believe a God who is ever and on all accounts represented such as to be actually a true model and example of the most exact justice and highest goodness and worth. Such a view of divine providence and bounty 35 
extended to all, and expressed in a constant good affection towards the whole, must of necessity engage us, within our compass and sphere, to act by a like principle and affection; and having once the good s of our species or public in view, as our end or aim, it is impossible we should be misguided by any means to a false apprehension or sense of right or wrong.

As to this second case therefore, religion (according as the kind may prove) is capable of doing so great good or harm, and atheism nothing positive in either way. For however it may be indirectly an occasion of men's losing a good and sufficient sense of right and wrong, it will not, as atheism merely, be the occasion of setting up a false species is of it, which only false religion or fantastical opinion, derived commonly from superstition and credulity, is able to effect.

\section{Section III.}

Now as to the last case, the opposition made zo by other affections to the natural sense of right and wrong.

It is evident that a creature having this sort of sense or good affection in any degree, must necessarily act according to it, if it happens not to be op2 s posed, either by some settled, sedate affection towards a conceived private good, or by some sudden, strong, and forcible passion ${ }^{1}$ as of lust or anger, which may not only subdue the sense of right and wrong, but the very sense of private good itself, and overrule even 3o the most familiar and received opinion of what is conducing to self-interest.

But it is not our business in this place to examine the several means or methods by which this corruption

1 Vgl. oben S. 32, Anm. 4. 
is introduced or increased. We are to consider only how the opinions concerning a Deity can influence ${ }^{1}$ one way or another.

That it is possible for a creature capable of using reflection to have a liking or dislike of moral actions, s and consequently a sense of right and wrong, before such time as he may have any settled notion of a God, is what will hardly be questioned; it being a thing not expected, or any way possible, that a creature such as man, arising from his childhood slowly and gra- ro dually to several degrees of reason and reflection, should at the very first be taken up ${ }^{2}$ with those speculations or more refined sort of reflections, about the subject of God's existence.

Let us suppose a creature who, wanting reason and is being unable to reflect, has notwithstanding many good qualities and affections, as love to his kind, courage, gratitude, or pity. 'Tis certain that if you give to this creature a reflecting faculty, it will at the same instant approve of gratitude, kindness, and pity; be 20 taken with ${ }^{3}$ any show or representation of the social passion, and think nothing more amiable than this, or more odious than the contrary. And this is to be capable of virtue, and to have a sense of right and wrong.

Before the time, therefore, that a creature can have any plain or positive notion one way or other, concerning the subject of a God, he may be supposed to have an apprehension or sense of right and wrong, and be possessed of virtue and vice in different degrees, 30

1 influence hier intransitiv "Einfluß ausüben, wirken».

2. to be taken up with speculations "sich mit Spekulationen beschäftigen').

3 (that it will) be taken with "daß es eingenommen, erfreut sein wird" von jedem Beweis u. s. w. 
as we know by experience of those who, having lived in such places and in such a manner as never to have entered into any serious thoughts of religion, are nevertheless very different among themselves, as to their s characters of honesty and worth: some being naturally modest, kind, friendly, and consequently lovers of kind and friendly actions; others proud, harsh, cruel, and consequently inclined to admire rather the acts of violence and mere power.

ro Now as to the belief of a Deity, and how men are influenced by it, we may consider, in the first place, on what account men yield obedience, and act in conformity to such a Supreme Being. It must be either in the way of his power, as preis supposing some disadvantage or benefit to accrue from him; or in the way of his excellency and worth, as, thinking it the perfection of nature, to imitate and resemble him.

If (as in the first case) there be a belief or con2o ception of a Deity who is considered only as powerful over his creature; and enforcing obedience to his absolute will by particular rewards and punishments; and if on this account through hope merely of reward, or fear of punishment, is the creature be incited to do the good he hates, or restrained from doing the ill to which he is not otherwise in the last degree averse, there is in this case (as has been already shown) no virtue or goodness whatsoever. The creature, not3o withstanding his good conduct, is intrinsically of as little worth as if he acted in his natural way, when under no dread or terror of any sort. There is no more of rectitude, pity, or sanctity in any creature thus reformed, than there is meekness or gentleness $3 i$ in a tiger strongly chained, or innocence and sobriety 
in a monkey under the discipline of the whip. For however orderly and well those animals, or man himself upon like terms, may be induced to act, whilst the will is neither gained nor the inclination wrought upon, but awe alone prevails and forces obedience, s the obedience is servile, and all which is done through it merely servile. The greater degree of such a submission or obedience is only the greater servility, whatever may be the object. For whether such a creature has a good master or an ill one, he so is neither more nor less servile in his own nature. $\mathrm{Be}$ the master or superior ever so perfect or excellent, yet the greater submission caused in this case, through this sole principle or motive, is only the lower and more abject servitude, and implies the greater wretchedness is and meanness in the creature, who has those passions of self-love so predominant, and is in his temper so vicious and defective as has been explained.

As to the second case. If there be a belief or conception of a Deity who is considered as worthy 20 and good, and admired and reverenced as such, being understood to have, besides mere power and knowledge, the highest excellence of Nature, such as renders him justly amiable to all; and if in the manner this Sovereign and mighty Being is represented, or as ${ }^{1}$ he is histori-25 cally described ${ }^{2}$, there appears in him a high and eminent regard to what is good and excellent, a concern for the good of all, and an affection of benevolence and love towards the whole, such an example must undoubtedly serve (as above explained) to raise 30 and increase the affection towards virtue, and help to submit and subdue all other affections to that alone.

1 as korrespondiert mit dem vorhergehenden in the manner.

2 bistorically described (in den Religionsurkunden geschildert». 
Nor is this good effected by example merely. For where the theistical belief ${ }^{1}$ is entire and perfect, there must be a steady opinion of the superintendency of a Supreme Being, a witness and spectator of human life, $s$ and conscious of whatsoever is felt or acted in the universe; so that in the perfectest recess or deepest solitude there must be One still presumed remaining with us, whose presence singly must be of more moment ${ }^{2}$ than that of to the most august assembly on earth. In such a presence, it is evident, that as the shame of guilty actions must be the greatest of any, so must the honour be of well-doing, even under the unjust censure of a world. And in this case 'tis is very apparent how conducing a perfect theism must be to virtue, and how great deficiency there is in atheism.

What the fear of future punishment and hope of future reward, added to this belief, may further 20 contribute towards virtue, we come now to consider more particularly. So much in the meanwhile may be gathered from what has been said above, that neither this fear nor hope can possibly be of the kind called good affec25 tions, such as are acknowledged the springs and sources of all actions truly good. Nor can this fear or hope, as above intimated ${ }^{3}$, consist in reality with virtuc or goodness, if it either stands as essential ${ }^{4}$ to any moral performance, or as a considerable motive

'theistical belief "Glaube an Gott".

2 moment "bewegende, treibende Kraft): of more moment "von größerem Gewicht, Einfluß».

3 intimated "nahe gelegt".

" essential "wesentlich", von essentia das wahre innere Wesen eines Dings; dem gr. üsía nachgebildet. 
to any act, of which some better affection ought alone to have been a sufficient cause. ${ }^{1}$

It may be considered withal, that in this religious sort of discipline ${ }^{2}$, the principle of self-love, which is naturally so prevailing in us, being no way moderated s or restrained, but rather improved and made stronger every day by exercise of the passions ${ }^{3}$ in a subject of more extended self-interest, there may be reason to apprehend lest the temper of this kind should extend itself in general through all the parts of life. For if so the habit be such as to occasion, in every particular, a stricter attention to self-good and private interest, it must insensibly diminish the affections towards public good or the interest of society, and introduce a certain narrowness of spirit, is which (as some pretend) is peculiarly observable in the devout persons and zealots of almost every religious persuasion.

This, too, must be confessed: that if it be true piety ${ }^{4}$ to love God for his own sake, the over- 20 solicitous regard to private good expected

1 Ähnlich Spinoza, Ethik II, Anm. am Ende: “Unsere Glückseligkeit besteht in der bloßen Erkenntnis Gottes, wodurch wir veranlabt ẇerden, nur das zu tun, was Liebe und Frömmigkeit (pietas) heischen. Daraus ersehen wir klar, wie weit jene von der wahren Schätzung der Tugend entfernt sind, die für Tugend und gute Handlungen, wie für sehr schwere Dienstleistungen, die höchsten Belohnungen von Gott erwarten; als ob die Tugend und der Dienst Gottes nicht selbst schon das Glück und die höchste Freiheit wären.»

${ }^{2}$ religious sort of discipline (religiöse Erziehungsart, kirchliche Zucht und Schulung', wie sie besonders in den Klöstern geübt wird und $z u$ den oben erwähnten Erscheinungen führt.

3 D. h. Furcht vor Höllenstrafen und Hoffnung auf ewigen Lohn im Himmel vermehren den frommen Egoismus.

"piety (Frömmigkeit», pity (Mitleid», vgl. frz. piélé und pitié; beide aus lat. pietas differenziert. 
from him must of necessity prove a diminution of piety. For whilst God is beloved only as the cause of private good, he is no otherwise beloved than as any other instrument or means of pleasure by $s$ any vicious creature. Now the more there is of this violent affection towards private good, the less room is there for the other sort towards goodness itself, or any good and deserving object, worthy of love and admiration for its own sake, such as God is universally so acknowledged, or at least by the generality of civilized or refined worshippers.

'Tis in this respect that the strong desire and love of life may also prove an obstacle to piety as well as to virtue and public love. For the stronger is this affection is in any one, the less will he be able to have true resignation, or submission to the rule and order of the Deity. And if that which he calls resignation depends only on the expectation of infinite retribution or reward, he dis20 covers $^{1}$ no more worth or virtue here than in any other bargain of interest. The meaning of his resignation being only this, That he resigns his present life and pleasures conditionally, for that which he himself confesses to be beyond an equiva2s lent: eternal living in a state of highest pleasure and enjoyment.

But notwithstanding the injury which the principle of virtue may possibly suffer by the increase of the selfish passion in the way we have been mentioning, 30 'tis certain, on the other side, that the principle of fear of future punishment, and hope of future reward, how mercenary or servile soever it may be accounted, is yet in many circumstances a great advantage, security, and support to virtue.

1 discovers "entfaltet, zeigt". 
It has been already considered, that notwithstanding there may be implanted in the heart a real sense of right and wrong, a real good affection towards the species or society, yet by the violence of rage, lust, or any other counterworking passion, this good affec- s tion may frequently be controlled ${ }^{1}$ and overcome. Where therefore there is nothing in the mind capable to render such ill passions the objects of its aversion, and cause them earnestly to be opposed, 'tis apparent how much a good temper in time must suffer, and a ro character by degrees change for the worse. But if religion, interposing, creates a belief that the ill passion of this kind, no less than their consequent actions, are the objects of a Deity's animadversion, 'tis certain that such a belief must prove a seasonable is remedy against vice, and be in particularmanner advantageous to virtue. For a belief of this kind must be supposed to tend considerably towards the calming of the mind, and disposing or fitting the person to a better recollection of himself and to a 20 stricter observance of that good and virtuous principle which needs only his attention to engage him wholly in its party and interest.

And as this belief of a future reward and punishment is capable of supporting those who, through ill 25 practice, are like to apostatise ${ }^{2}$ from virtue, so when by ill opinion and wrong thought the mind itself is bent against the honest course, and debauched ${ }^{3}$ even to an esteem and deliberate preference of a vicious

1 controlled (unterdrückt, beeinträchtigt); Grundwort contrerôle, Gegenrechnung, Kontrolle, daher to control beaufsichtigen, beherrschen.

2 apostatise "abfallen», vom gr. apostătēs "der Abtrünnige» gebildet.

3 debauched "verführt). 
one, the belief of the kind mentioned may proof on this occasion the only relief and safety.

A person, for instance, who has much of goodness and natural rectitude in his temper, but withal so much s softness or effeminacy as unfits him to bear poverty, crosses, or adversity, if by ill fortune he meets with many trials of this kind, it must certainly give a sourness and distaste to his temper, and make him exceedingly averse to that which he may falsely presume ro the occasion of such calamity or ill. Now if his own sorts, or the corrupt insinuations ${ }^{1}$ of other men, present it often to his mind that his honesty is the occasion of this calamity, and that if he were delivered from this restraint of virtue and honesty, he might be much is happier, 'tis very obvious that his esteem of these good qualities must in proportion diminish every day as the temper grows uneasy and quarrels with itself. But if he opposes to this thought the consideration that honesty carries with it, if not a present, at least a 2o future advantage, such as to compensate that loss of private good which he regrets, then may this injury to his good temper and honest principle be prevented, and his love or affection towards honesty and virtue remain as it was before.

${ }_{25}$ Thus in a civil state or public $^{2}$ we see that a virtuous administration, and an equal and just distribution of rewards and punishments, is of the highest service, not only by restraining the vicious and forcing them to act usefully to society, but by making virtue to be 30 apparently the interest of everyone, so as to remove all prejudices against it, create a fair reception for it, and lead men into that path which afterwards they cannot easily quit. For thus a people, raised from

1 insinuations "Einflüsterungen, Zumutungen».

2 public "Gemeinwesen". 
barbarity or despotic rule, civilised by laws and made virtuous by the long course of a lawful and just administration, if they chance to fall suddenly under any misgovernment of unjust and arbitrary power, they will on this account be the rather animated to exert ; a stronger virtue in opposition to such violence and corruption.

But though a right distribution of justice in a government be so essential a cause of virtue, we must observe in this case that it is example which ro chiefly influences mankind, and forms the character and disposition of a people. For a virtuous administration is in a manner necessarily accompanied with virtue in the magistrate. Otherwise it could be of little effect, and of no long duration. is But where it is sincere and well established, there virtue and the laws must necessarily be respected and beloved. So that, as to punishments and rewards, their efficacy is not so much from the fear or respectation which they raise, as from a natural esteem of 20 virtue and detestation of villany, which is awakened and excited by these public expressions of the approbation and hatred of mankind in each case.

And as the case of reward and punishment stands thus in the public, so, in the same manner, as to pri- 25 vate families. For slaves and mercenary servants, restrained and made orderly by punishment and the severity of their master, are not on this account made good or honest. Yet the same master of the family using proper rewards and gentle punishments towards 30 his children, teaches them goodness, and by this help instructs them in a virtue which afterwards they practise upon other grounds, and without thinking of a penalty or bribe ${ }^{1}$. And

1 bribe "Bestechung, Vergütung». 
this is what we call a liberal education and a liberal service; the contrary service and obedience, whether towards God or man, being illiberal and unworthy of any honour or commendation.

s Such are the advantages or disadvantages which accrue to virtue from reflection upon private good or interest. For though the habit of selfishness and the multiplicity of interested views are of little improvement to real merit or virtue, yet there is a necessity so for the preservation of virtue, that it should be so to have no quarrel with true interest and self-enjoyment.

Whoever, therefore, by any strong persuasion or settled judgment, thinks in the main that virtue causes happiness and vice misery, is carries with him that security and assistance to virtue which is required. Or though he has no such thought, nor can believe virtue his real interest, either with respect to his own nature and constitution, or the circumstances of human life, yet 20 if he believes any supreme powers concerned in the present affairs of mankind, immediately interposing in behalf of the honest and virtuous against the impious and unjust, this will serve to preserve in him, however, that just esteem of virtue which might ss otherwise considerably diminish. Or should he still believe little of the immediate interposition of Providence in the affairs of this present life, yet if he believes a God dispensing rewards and punishments to vice and virtue in a future, he carries 3o with him still the same advantage and security, whilst his belief is steady and nowise wavering or doubtful. For it must be observed, that an expectation and dependency so miraculous and great as this, must naturally take off from other inferior dependencies and ss encouragements. Where infinite rewards are thus en- 
forced, and the imagination strongly turned towards them, the other common and natural motives to goodness are apt to be neglected and lose much by disuse. Other interests are hardly so much as computed, whilst the mind is thus transported in the pursuit of a high s advantage, and self-interest so narrowly confined within ourselves. On this account all other affections towards friends, relations, or mankind are often slightly regarded, as being worldly and of little moment in respect of the interest of our soul. And so little ro thought is there of any immediate satisfaction arising from such good offices of life, that it is customary with many devout people zealously to decry all temporal advantages of goodness, all natural benefits of virtue, and magnifying the contrary happiness of a vicious is state $^{1}$, to declare that except only for the sake of future reward and fear of future punishment they would divest themselves of all goodness at once, and freely allow themselves to be most immoral and profligate $^{2}$. From whence it appears that in some respects 20 there can be nothing more fatal to virtue than the weak and uncertain belief of a future reward and punishment. For the stress being laid wholly here ${ }^{3}$, if this foundation come to fail, there is no further prop or security to men's morals. And thus 2 virtue is supplanted and betrayed.

Now as to atheism; though it be plainly deficient and without remedy, in the case of ill judgment on the happiness of virtue, yet it is not, indeed, of necessity the cause of any such ill judgment. For without 30

1 vicious state (of things) (lasterhafter Zustand».

2profligate "niederträchtig, verworfen, ruchlos»; von profligare, niederschlagen, zugrunde richten.

3 for the stress being laid wholly here «indem man alles Gewicht, allen Nachdruck gerade hierauf legt»).

R uska, Anthony Earl of Shaftesbury. 
an absolute assent to any hypothesis of theism, the advantages of virtue may possibly be seen and owned, and a high opinion of it established in the mind. However it must be confessed that the natural ten$s$ dency of atheism is very different.

'Tis in a manner impossible to have any great opinion of the happiness of virtue without conceiving high thoughts of the satisfaction resulting from the generous admiration and love of it; and nothing bero sides the experience of such a love is likely to make this satisfaction credited. The chief ground and support therefore of this opinion of happiness in virtue must arise from the powerful feeling of this generous moral affection, and the knows ledge of its power and strength. But this is certain, that it can be no great strengthening to the moral affection, no great support to the pure love of goodness and virtue, to suppose there is neither goodness, nor beauty in the Whole itself ${ }^{1}$; nor any example so or precedent of good affection in any superior Being. Such a belief must tend rather to the weaning ${ }^{2}$ the affections from anything amiable or self-worthy, and to the suppressing the very habit and familiar custom of admiring natural beauties, or whatever in the order 25 of things is according to just design, harmony, and proposition. For how little disposed must a person be to love or admire anything as orderly in the universe who thinks the universe itself a pattern of disorder? How inapt to reverence or respect any particular so subordinate beauty of a part, when even the Whole

${ }^{1}$ Blind für die Ordnung und Schönheit des Weltalls zu sein, ist der besondere Vorwurf, den Shaftesbury den Atheisten macht; wic umgekehrt der Theismus einen seiner Gottesbeweise, den "kosmologischen", eben dieser Ordnung des Weltalls entnimmt.

2 weaning "entwöhnen». 
itself is thought to want perfection, and to be only a vast and infinite deformity?

Nothing indeed can be more melancholy than the thought of living in a distracted ${ }^{1}$ universe, from whence many ills may be suspected, and where there is nothing s good or lovely which presents itself, nothing which can satisfy in contemplation, or rise any passion besides that of contempt, hatred, or dislike. Such an opinion as this may by degrees embitter the temper, and not only make the love of virtue to be less felt, but help so to impair and ruin the very principle of virtue, viz. natural and kind affection.

Upon the whole, whoever has a firm belief of a God whom he does not merely call good, but of whom in reality he believes nothing beside real good, is nothing beside what is truly suitable to the exactest character of benignity and goodness; such a person believing rewards or retributions in another life, must believe them annexed to real goodness and merit, real villainy and baseness, and not to any acci- 20 dental qualities or circumstances, in which respect they, cannot properly be styled rewards or punishments, but capricious distributions of happiness or unhappiness to creatures. These are the only terms on which the belief of a world to come can happily in-2s fluence the believer. And on these terms, and by virtue of this belief, man perhaps must retain his virtue and integrity, even under the hardest thoughts of human nature, when either by any ill circumstance or untoward doctrine he is brought to that infortunate opi- 30 nion of Virtue's being naturally an enemy to happiness in life.

This, however, is an opinion which cannot be supposed consistent with sound theism. For whatever be

1 distracted (zerrüttet), gesetzlos und ungeordnet. 
decided as to a future life, or the rewards and punishments of hereafter, he who, as a sound theist, believes a reigning mind sovereign in Nature, and ruling all things with the highest perfecstion of goodness, as well as of wisdom and power, must necessarily believe virtue to be naturally good and advantageous. For what could more strongly imply an unjust ordinance, a plot and imperfection in the general constitution of things, than so to suppose virtue the natural ill, and vice the natural good of any creature?

This is certain, that the admiration and love of order, harmony, and proportion, in whatever kind, is naturally improving to the temper, advantageous to sois cial affection, and highly assistant to virtue, which is itself no other than the love of order and beauty in society. In the meanest subjects of the world, the appearence of order gains upon the mind and draws the affection towards it. But if the order of the world 20 itself appears just and beautiful, the admiration and esteem of order must run higher, and the elegant passion $^{1}$ or love of beauty, which is so advantageous to virtue, must be the more improved by its exercise in so ample and magnificent a subject. For it is im${ }^{2}$ possible that such a divine order should be contemplated without ecstasy and rapture ${ }^{2}$, since

1 the elegant passion "die anmutige, schöne Leidenschaft, der Enthusiasmus", weiter unten divine passion.

${ }^{2}$ Als ein Beispiel für Shaftesburys Naturbegeisterung seien die folgenden Zeilen aus den Moralists (II, '98) angeführt:

"O glorious Nature! supremely fair and sovereignly good! all-loving and all lovely, all-divine! whose looks are so becoming and of such infinite grace, whose study brings such wisdom, and whose contemplation such delight; whose every single work affords an ampler scene, and is a nobler spectacle than all which ever art presented! $\mathrm{O}$ mighty Nature! wise substitute of Providence! 
in the common subjects of science and the liberal arts, whatever is according to just harmony and proportion is so transporting to those who have any knowledge or practice in the kind.

Now if the subject and ground of this divines passion be not really just or adequate (the hypothesis of theism being supposed false) the passion still in itself is so far natural and good, as it proves an advantage to virtue and goodness, according to what has been above demonstrated. But if, on the other side, ro the subject of this passion be really adequate and just (the hypothesis of theism being real, and not imaginary), then is the passion also just, and becomes absolutely due and requisite in every rational creature.

Hence we may determine justly the relation which is Virtue has to Piety, the first being not complete but in the latter, since where the latter is wanting, there can neither be the same benignity or constancy, the same good composure of the affections or uniformity of mind.

And thus the perfection and height of virtue must be owing to the belief of a God.

impowered creatress! Or thou impowering Deity, supreme creator! Thee I invoke and thee alone adore. To thee this solitude, this place, these rural meditations are sacred; whilst thus inspired with harmony of thought, though unconfined by words, and in loose numbers, I sing of Nature's order in created beings, and celebrate the beauties which resolve in thee, the source and principle of all beauty and perfection.» 


\section{BOOK II.}

\section{PART I.}

\section{Section I.}

We have considered what virtue is and to whom s the character ${ }^{1}$ belongs. It remains to inquire, what obligation $^{2}$ there is to virtue, or what reason, to embrace it.

We have found that, to deserve the name of good or virtuous, a creature must have all his inclinations to and affections, his dispositions of mind and temper, suitable, and agreeing with the good of his kind, or of that system in which he is included, and of which he constitutes a part. To stand thus well affected, and to have one's affections right and entire, not only in is respect of oneself but of society and the public, this is rectitude, integrity, or virtue. And to be wanting in any of these, or to have their contraries, is depravity, corruption, and vice.

It has been already shown, that in the passions 20 and affections of particular creatures there is a constant relation to the interest of a species or common nature. ${ }^{3}$ This has been demonstrated in the

1 character ergänze of being virtuous.

2 obligalion "Verbindlichkeit", Verpflichtung.

- Vgl. Book I, S. 27 und folgende. 
case of natural affection, parental kindness, concern for the nurture of the young, love of fellowship and company, compassion, mutual succour, and the rest of this kind. Nor will any one deny that this affection of a creature towards the good of the species or common s nature is as proper and natural to him as it is to any organ, part, or member of an animal body, or mere vegetable, to work in its known course and regular way of growth. 'Tis not more natural for the stomach to digest, the lungs to breathe, the glands to separate so juices ${ }^{1}$, or other entrails to perform their several offices, however they may by particular impediments be sometimes disordered or obstructed in their operations.

There being allowed therefore in a creature such affections as these towards the common nature or is system of the kind, together with those other which regard the private nature or self-system, it will appear that in following the first of these affections, the creature must on many occasions contradict and go against the latter. How else 20 should the species be preserved? Or what would signify that implanted natural affection, by which a creature through so many difficulties and hazards ${ }^{2}$ preserves its offspring and supports its kind?

It may therefore be imagined, perhaps, that there 25 is a plain and absolute opposition between these two habits or affections. It may be presumed that the pursuing of the common interest or public good through the affections of one kind, must be a hindrance to the attainment of private good through the affections of 30 another. For it being taken for granted that hazards

1 the glands to separate juices “die Drüsen, Säfte abzusondern».

2 hazards "Gefahren», aus dem frz. hasard, Würfelspiel, Zufall, Gefahr - Ableitung aus dem Arab. unsicher, Begriffsreihe leicht verständlich. 
and hardships of whatever sort are naturally the ill of the private state, and it being certainly the nature of those public affections to lead often to the greatest hardships and hazards of every kind, 'tis presently ; inferred "that 'tis the creature's interest to be without any public affection whatsoever". 1

This we know for certain, that all social love, friendship, gratitude, or whatever else is of this generous kind, does by its nature take place of the selfso interesting passions, draws us out of ourselves, and makes us disregardful of our own convenience and safety. So that according to a known way of reasoning on self-interest, that which is of a social kind in us should of right be abolished. Thus kindness of is every sort, indulgence, tenderness, compassion, and, in short, all natural affection, should be industriously suppressed, and as mere folly and weakness of nature be resisted and overcome; that by this means there might be nothing remaining in us which was contrary to a 2o direct self-end; nothing which might stand in opposition to a steady and deliberate pursuit of the most narrowly confined self-interest.

According to this extraordinary hypothesis, it must be taken for granted that in the system of a kind or 2s species, the interest of the private nature is directly opposite to that of the common one, the interest of

1 Hier und im Folgenden wendet sich Shaftesbury gegen Thomas Hobbes (1588-1679), der als Grundtrieb der menschlichen Natur einzig und allein den Egoismus gelten ließ und die sozialen Neigungen nicht als ursprünglich anerkannte, sondern als sekundäre Wirkungen des Selbsterhaltungstriebs betrachtete. Danach muf jeder Mensch alle andern als seine geborenen Feinde bekämpfen; aus diesem Naturzustand des "Kriegs aller gegen all(') entsteht durch freiwilliges Übereinkommen, durch eine Art Vertrag, der Staat, das soziale System, in welchem die egoistischen 'Triebe ihren Ausgleich finden. 
particulars directly opposite to that of the public in general. A strange constitution! in which it must be confessed there is much disorder and untowardness, unlike to what we observe elsewhere in Nature. As if in any vegetable or animal body the part or member s could be supposed in a good and prosperous state as to itself, when under a contrary disposition and in an unnatural growth or habit as to its whole! ${ }^{1}$

Now that this is in reality quite otherwise, we shall endeavour to demonstrate, so as to make appear that ro what men represent as an ill order and constitution in the universe, by making moral rectitude appear the ill, and depravity the good or advantage of a creature ${ }^{2}$, is in Nature just the contrary. That to be well affected towards the public interest and one's is own is not only consistent but inseparable; and that moral rectitude or virtue must accordingly be the advantage, and vice the injury and, disadvantage of every creature.

\section{Section III.}

It has been shown before, that no animal can be said properly to act otherwise than through affections or passions, such as are proper to an animal. For in convulsive fits, where a creature strikes either himself or others, 'tis a simple mechanism, an engine, or piece 25 of clockwork, which acts, and not the animal.

Whatsoever therefore is done or acted by any animal as such, is done only through some

1 Vgl. die bekannte Fabel des Konsuls Menenius Agrippa bei der ersten Sezession derPlebejer auf den Heiligen Berg (496 v. Chr.).

2 In der verwegensten Form wurde dieser Gedanke von B. de Mandeville (1670-I733) zuerst 1699 in seiner sogenannten Bienenfabel ("The grumbling hive or knaves turned honest") ausgesprochen. 
affection or passion, as of fear, love, or hatred moving him.

And as it is impossible that a weaker affection should overcome a stronger ${ }^{1}$, so it is impossible but s that where the affections or passions are strongest in the main, and form in general the most considerable party, either by their force or number, thither the animal must incline: and according to this balance ${ }^{2}$ he must be governed and led to action.

so The affections or passions which must influence and govern the animal are either:

I. The natural affections, which lead to the good of the public.

2. Or the self affections, which lead only to the is good of the private.

3. Or such as are neither of these, nor tending either to any good of the public or private, but contrarywise; and which may therefore be justly styled unnatural affections.

20 So that according as these affections stand, a creature must be virtuous or vicious, good or ill.

The latter sort of these affections, 'tis evident, are wholly vicious. The two former may be vicious or virtuous according to their degree.

is It may seem strange, perhaps, to speak of natural affections as too strong, or of self affections as too weak. But to clear this difficulty we must call to mind what has been already explained, that natural affection may, in particular cases, be excessive,

1 Spinoza, Ethik IV, 7: "Ein Affekt kann nicht anders gehemmt oder aufgehoben werden als durch einen andern, entgegengesetzten und stärkeren Affekt).

2 according to this balance "entsprechend diesem Übergewicht); balance Wage v. lat. bi-lanx, wörtlich Doppelschale (vgl. scale, scales). 
and in an unnatural degree. As when pity is so overcoming as to destroy its own end, and prevent the succour and relief required; or as when love to the offspring proves such a fondness as destroys the parent, and consequently the offspring itself. And notwith- s standing it may seem harsh to call that unnatural and vicious which is only an extreme of some natural and kind affection, yet 'tis most certain that wherever any single good affection of this sort is over-great, it must be injurious to the rest, and detract in some measure to from their force and natural operation. For a creature possessed with such an immoderate degree of passion, must of necessity allow too much of that one, and too little to others of the same character, and equally natural and useful as to their end. And this must ne- is cessarily be the occasion of partiality and injustice whilst only one duty or natural part ${ }^{1}$ is earnestly followed, and other parts and duties neglected, which should accompany it, and perhaps take place and be preferred.

This may well be allowed true in all other respects, since even religion itself, considered as a passion, not of the selfish but nobler kind, may in some characters be strained beyond its natural proportion, and be said also to be in too high a degree. For as the end of 25 religion is to render us more perfect and accomplished in all moral duties and performances; if by the height of devout ecstasy and contemplation we are rather disabled in this respect, and rendered more unapt to the real duties and offices of 30 civil life, it may be said that religion indeed is then too strong in us. For how, possibly, can we call this superstition, whilst the object of the devotion is acknow-

1 part «Rolle, Aufgabe, Funktion». 
ledged just and the faith orthodox? 'Tis only the excess of zeal which in this case is so transporting as to render the devout person more remiss in secular affairs ${ }^{1}$, and less concerned for the inferior and temporal interests $s$ of mankind.

Now as in particular cases public affection, on the one hand, may be too high, so private affection may, on the other hand, be too weak. For if a creature be self-neglectful and insensible of danger, or if he want to such a degree of passion in any kind as is useful to preserve, sustain, or defend himself, this must certainly be esteemed vicious in regard of the design and end of Nature. She herself discovers this in her known method and stated rule of operation. 'Tis certain that is her provisionary care and concern for the whole animal must at least be equal to her concern for a single part or member. Now to the several parts she has given, we see proper affections, suitable to their interest and security, so that even without our consciousness they 2o act in their own defence, and for their own benefit and preservation. Thus an eye, in its natural state, fails not to shut together of its own accord, unknowingly to us, by a peculiar caution and timidity, which if it wanted, however we might intend the preservation of is our eye, we should not in effect be able to preserve it, by any observation or forecast of our own. To be wanting therefore in those principal affections which respect the good of the whole constitution, must be a vice and imperfection as great surely in the principal ${ }^{30}$ part (the soul or temper), as it is in any of those in-

${ }^{1}$ secular affairs "weltliche Angelegenheiten»; saecularis eigentl.: zum Zeitalter, zum gegenwärtigen Geschlecht gehörig, dann auf das diesseitige Leben (im Gegensatz zur Ewigkeit) sich beziehend; kirchlicher Ausdruck, gleichbed. mit temporal. 
ferior and subordinate parts to want the self-preserving affections which are proper to them.

And thus the affections towards private good become necessary and essential to goodness. For though no creature can be called good or vir- s tuous merely for possessing these affections, yet since it is impossible that the public good or good of the system can be preserved without them, it follows that a creature really wanting in them is in reality wanting in some degree to goodness and natural rectitude, and to may thus be esteemed vicious and defective.

'Tis thus we say of a creature, in a kind way of reproof, that he is too good, when his affection towards others is so warm and zealous as to carry him even beyond his part; or when he really acts beyond it, not is through too warm a passion of that sort, but through an over-cool one of another, or through want of some self-passion to restrain him within due bounds.

It may be objected here, that the having the natural affections too strong (where the self- 20 affections are overmuch so), or the having the selfaffections defective or weak (where the natural affections are also weak), may prove up on occasion the only cause of a creature's acting honestly and in moral proportion. For, thus, one who is to a 25 fault regardless of his life, may with the smallest degree of natural affection do all which can be expected from the highest pitch of social love or zealous friendship. And thus, on the other hand, a creature excessively timorous may, by as exceeding a degree of natural 30 affection, perform whatever the perfectest courage is able to inspire.

To this it is answered, that whenever we arraign ${ }^{1}$

1 arraign «anklagen, beschuldigen». 
any passion as too strong, or complain of any as too weak, we must speak with respect to a certain constitution or economy ${ }^{1}$ of a particular creature or species. For if a passion, leading to any s right end, be only so much the more serviceable and effectual for being strong, if we may be assured that the strength of it will not be the occasion of any disturbance within, nor of any disproportion between itself and other affections, then consequently the passion, so however strong, cannot be condemned as vicious. But if to have all the passions in equal proportion with it, be what the constitution of the creature cannot bear, so that only some passions are raised to this height, whilst others are not, nor can possibly be wrought up is to the same proportion, then may those strong passions, though of the better kind, be called excessive.

But to show more particularly what is meant by the economy ${ }^{1}$ of the passions, from instances in the species or kinds below us. As for the creatures who so have no manner of power or means given them by Nature for their defence against violence, nor anything by which they can make themselves formidable to such as injure or offend them, 'tis necessary they should have an extraordinary degree of fear, but little or no is animosity, such as might cause them to make resistance, or incline them to delay their flight. For in this their safety lies, and to this passion of fear is serviceable, by keeping the senses on the watch, and holding the spirits in readiness to give the start ${ }^{2}$.

30 And thus timorousness, and an habitual strong passion of fear, may be according to the economy of a

${ }^{1}$ economy «Bau, Einrichtung; Ordnung, Harmonie, richtiges Verhältnis". Vgl. S. 23, Anm. 4.

"to give the start "Fersengeld zu geben, das Hasenpanier zu ergreifen"; umgekehrt to make head. 
particular creature, both with respect to himself and to the rest of his species. On the other hand, courage may be contrary to his economy, and therefore vicious. Even in one and the same species, this is by Nature differently ordered, with respect to different sexes, ages, s and growths. The tamer creatures of the grazing kind, who live in herds, are different from the wilder, who herd not, but live in pairs only, apart from company, as is natural and suitable to their rapacious life. Yet is there found, even among the former inoffensive kind, to a courage proportionable to their make and strength. At a time of danger, when the whole herd flies, the bull alone makes head against the lion, or other whatever invading beast of prey, and shows himself conscious of his make. But for creatures who are able to is make resistance, and are by Nature armed offensively, be they of the poorest insect kind, such as bees or wasps, 'tis natural to them to be roused with fury, and at the hazard of their lives to oppose any enemy or invader of their species. For by this known 20 passion in the creature, the species itself is secured, when by experience 'tis found that the creature, though unable to repel the injury, yet voluntarily exposes his life for the punishment of the invader, and suffers not his kind to be injured with impunity. And 25 of all other creatures, man is in this sense the most formidable, since if he thinks it just and exemplary, he may, possibly in his own or in his country's cause, revenge an injury on any one living, and by throwing away his own life (if he be resolute to that 30 degree) is almost certain master of another's, however strongly guarded. Examples of this nature have often served to restrain those in power from using it to the utmost extent, and urging their inferiors to extremity. 
Upon the whole, it may be said properly to be the same with the affections or passions in an animal constitution as with the chords or strings of a musical instrument. If these, though in ever so just proportion $s$ one to another, are strained beyond a certain degree, 'tis more than the instrument will bear: the lute ${ }^{\mathbf{1}}$ or lyre ${ }^{2}$ is abused, and its effect lost. On the other hand, if while some of the strings are duly strained, others are not wound up to their due proportion, then is the to instrument still in disorder, and its part ill performed. The several species of creatures are like different sorts of instruments; and even in the same species of creatures (as in the same sort of instrument) one is not entirely like the other, nor will the same strings fit is each. The same degree of strength which winds up one, and fits the several strings to a just harmony and consort $^{3}$, may in another burst both the strings and instrument itself. Thus men who have the liveliest sense, and are the easiest affected with pain or pleasure, have 20 need of the strongest influence or force of other affections, such as tenderness, love, sociableness, compassion, in order to preserve a right balance within, and to maintain them in their duty, and in the just performance of their part, whilst others, who are of is a cooler blood, or lower $\mathrm{key}^{4}$, need not the same allay or counterpart, nor are made by Nature to feel those tender and endearing affections in so exquisite a degree.

It might be agreeable, one would think, to inquire

1 lute "Laute», ein von den Arabern nach Spanien eingeführtes guitarrenartiges Saiteninstrument; der Name kommt v. arab. al-cûd.

2 lyre "Leier» ist nicht die antike Lyra, sondern ein späteres kastenförmiges Saiteninstrument.

s consort "Vereinigung, Zusammenklang".

4 lower key, der Musik entnommenes Bild: "tieferer Schlüssel», ruhigeres Temperament. 
thus into the different tunings of the passions, the various mixtures and allays by which men become so different from one another. For as the highest improvements of temper are made in human kind, so the greatest corruptions and degeneracies are discoverable s in this race. In the other species of creatures around us, there is found generally an exact proportionableness, constancy, and regularity in all their passions and affections; no failure in the care of the offspring or of the society to which they are united; no intemperance ro or excess in any kind. The smaller creatures, who live as it were in cities $^{1}$ (as bees and ants), continue the same train and harmony of life, nor are they ever false to those affections which move them to operate towards their public good.

Even those creatures of prey who live the farthest out of society, maintain, we see, such a conduct towards one another as is exactly suitable to the good of their own species. Whilst man, notwithstanding the assistance of religion and the direction of laws, is often found 20 to live in less conformity with Nature, and by means of religion itself is often rendered the more barbarous and inhuman. Marks are set on $\mathrm{men}^{2}$; distinctions formed; opinions decreed under the severest penalties; antipathies instilled, and aversions raised in men against 25 the generality of their own species. So that 'tis hard to find in any region a human society which has human laws. No wonder if in such societies 'tis so hard to find a man who lives naturally and as a man.

1 cities "Staaten» oder "Völker» - hat hier die ursprüngliche Bedeutung von civitas als "Gesamtheit der Bürger» bewahrt, aus der cité und city hervorgingen.

2 marks are set on men "besondere Kennzeichen werden den Menschen aufgeprägt).

Ruska, Anthony Earl of Shaftesbury. 
But having shown what is meant by a passion's being in too high or in too low a degree; and that to have any natural affection too high, or any self-af. fection too low, though it be often approved as s virtue, is yet strictly speaking, a vice and imperfection; we come now to the plainer and more essential part of vice, and which alone deserves to be considered as such; that is to say

I. When either the public affections are weak or ro deficient.

2. Or the private and self-affections too strong.

3. Or that such affections arise as are neither of these, nor in any degree tending to the support either of the public or private system.

is Otherwise than thus, it is impossible any creature can be such as we call ill or vicious. So that if once we prove that it is really not the creature's interest to be thus viciously affected, but contrariwise, we shall then have 20 proved that it is his interest to be wholly good and virtuous, since in a wholesome and sound state of his affections, such as we have described, he cannot possibly be other than sound, good, and virtuous in his action and behaviour.

25 Our business, therefore, will be to prove

I. That to have the natural, kindly, or generous affections strong and powerful towards the good of the public, is to have the chief means and power of self-enjoyment; and, that to want them, is misery $3^{\circ}$ and ill.

2. That to have the private or self-affections too strong, or beyond their degree of subordinacy to the kindly and natural, is also miserable.

3. And that to have the unnatural affections (viz. is such as are neither founded on the interest of the kind 
or public, nor of the private person or creature himself) is to be miserable in the highest degree.

\section{PART II.}

\section{Section I.}

To begin therefore with this proof, that to haves the natural affection (such as are founded in love, complacency, good-will, and in a sympathy with the kind or species) is to have the chief means and power of self-enjoyment; and that to want them is certain misery and ill.

We may inquire first what those are which we call pleasures or satisfactions ${ }^{1}$, from whence happiness is generally computed. They are (according to the common distinction) satisfaction and pleasures either of the body or of the mind.

That the latter of these satisfactions are the greatest, is allowed by most people, and may be proved by this: that whenever the mind, having conceived a high opinion of the worth of any action or behaviour, has received the strongest impression of 20 this sort, and is wrought up to the highest pitch or degree of passion towards the subject, at such time it sets itself above all bodily pain as well as pleasure, and can be no way diverted from its purpose by flattery or terror of any kind. Thus we see Indians, bar- 25 barians, malefactors, and even the most execrable ${ }^{2}$ villains, for the sake of a particular gang ${ }^{3}$ or society, or through some cherished notion or principle of honour

1 pleasures or satisfactions "Freuden oder angenehme, befriedigende, wohltuende Empfindungen».

2 execrable "fluchwürdig»; das Grundwort sacer "den Göttern geweiht) kann ebenso (heilig» wie "verflucht» bedeuten.

${ }^{3}$ gang (Rotte, Bande, Partei». 
or gallantry ${ }^{1}$, revenge or gratitude, embrace any manner of hardship, and defy torments and death. Whereas, on the other hand, a person being placed in all the happy circumstances of outward enjoyment, surrounded s with everything which can allure or charm the sense, yet no sooner has he conceived any internal ail ${ }^{2}$ or disorder, anything inwardly vexatious or distempered, than instantly his enjoyment ceases, the pleasure of sense is at an end, and every means of that sort beso comes ineffectual, and is rejected as uneasy and subject to give distaste.

The pleasures of the mind being allowed, therefore, superior to those of the body, it follows that whatever can create in any intelligent being a conis stant flowing series or train of mental enjoyments, or pleasures of the mind, is more considerable to his happiness than that which can create to him a like constant course or train of sensual enjoyments or pleasures of the body. 2o Now the mental enjoyments are either actually the very natural affections themselves in their immediate operations, or they wholly, in a manner, proceed from them, and are no other than their effects.

25 If so, it follows that, the natural affections duly established in a rational creature being the only means which can procure him a constant series or succession of the mental enjoyments, they are the only means which can procure him a certain and solid hapio piness.

Now, in the first place, to explain how much the natural affections are in themselves the highest plea-

1 some cherished notion . . of gallantry «irgend ein besonders gepflegter Begriff von Ehre oder Ritterlichkeit».

" internal ail (inneres Unbehagen, schmerzhaftes Gefühl». 
sures and enjoyments, there should methinks be little need of proving this to any one of human kind who has ever known the condition of the mind under a lively affection of love, gratitude, bounty, generosity, pity, succour, or whatever else is of a social or friendly sort. s $\mathrm{He}$ who has ever so little knowledge of human nature is sensible what pleasure the mind perceives when it is touched in this generous way. The difference we find between solitude and company, between a common company and that of friends; the reference of almost so all our pleasures to mutual converse, and the dependence they, have on society either present or imagined; all these are sufficient proofs in our behalf.

There is no one who, by the least progress in science or learning, has come to know barely the is principles of mathematics, but has found, that in the exercise of his mind on the discoveries he there makes, though merely of speculative truths, he receives a pleasure and delight superior to that of sense. When we have thoroughly searched into the nature of this con- 20 templative delight, we shall find it of a kind which relates not in the least to any private interest of the creature, nor has for its object any self-good or advantage of the private system. The admiration, joy, or love turns wholly upon what is exterior and foreign 25 to ourselves. And though the reflected joy ${ }^{1}$ or pleasure which arises from the notice of this pleasure once perceived, may be interpreted a self-passion or interested regard, yet the original satisfaction can be no other than what results from the love of truth, 30 proportion, order and symmetry in the things without. If this be the case, the passion ought in reality to be ranked with natural affection. For having

1 reflected joy (wiedergespiegelte Freude». 
no object within the compass of the private system, it must either be esteemed superfluous and unnatural (as having no tendency towards the advantage or good of anything in Nature), or it must be judged to be what $s$ it truly is, a natural joy in the contemplation of those numbers, that harmony, proportion, and concord which supports the universal nature, and is essential in the constitution and form of every particular species or order of beings.

But this speculative pleasure ${ }^{1}$, however considerable and valuable it may be, or however superior to any notion of mere sense, must yet be far surpassed by virtuous motion, and the exercise of benignity and goodness, where, tois gether with the most delightful affection of the soul, there is joined a pleasing assent and approbation of the mind to what is acted in this good disposition and honest bent. For where is there on earth a fairer matter of speculation, a goodlier view of contemplation, zo than that of a beautiful, proportioned, and becoming action? ${ }^{2}$

${ }^{1}$ Es ist ein charakteristischer Unterschied zwischen den Anschauungen der meisten griechischen und englischen Denker, da die rein spekulative, wissenschaftliche Betrachtung der Dinge, die jene am höchsten stellten, von diesen gegen die Betätigung der Kräfte im öffentlichen Leben, zum Besten der Gesellschaft, zurückgesetzt wird. Daß Wissen zugleich Macht ist, und da $\$$ diese Macht über die Natur vom Menschen ausgenützt werden müsse, ist besonders Francis Bacon ( $1561-1626$ ) nie müde geworden $z u$ verkünden.

${ }^{2} \mathrm{Ob}$ diese Selbstbespiegelung in den eigenen guten Werken wirklich das höchste Vergnügen oder auch nur jedermann sympathisch ist, darf wohl bezweifelt werden. Welche Rolle die Eitelkeit dabei spielt, wird auch von Shaftesbury nicht übersehen. Vgl. hiermit Spinozas Ethik III, Satz 53: Wenn der Geist sich selbst und sein Tätigkeitsvermögen betrachtet, enspindet er Lust. . . . Diese Lust wird mehr und mehr genährt, je mehr der Mensch 
Now, in the next place, to explain how the mental enjoyments proceed from the natural affections, as their natural effects, we may consider first, that the effects of love or kind affection, in a way of mental pleasure, are an enjoyment of good by s communication, a receiving it, as it were, by reflection, or by way of participation in the good of others; and, secondly, a pleasing consciousness of the actual love, merited esteem, or approbation of others.

How considerable a part of happiness arises from ro the former of these effects will be easily apprehended by one who is not exceedingly ill-natured. It will be considered how many the pleasures are of sharing contentment and delight with others; of receiving it in fellowship and company; and gathering it, in a manner, is from the pleased and happy states of those around us, from accounts and relations of such happinesses, from the very countenances, gestures, voices and sounds, even of creatures foreign to our kind, whose signs of joy and contentment we can any way discern. So in- 20 sinuating are these pleasures of sympathy, and so widely diffused through our whole lives, that there is hardly such a thing as satisfaction or contentment of which they make not an essential part.

As for that other effect of social love, viz. the 25 consciousness of merited kindness or esteem, 'tis not difficult to perceive how much this avails in mental pleasure and constitutes the chief enjoyment and happiness of man. What tyrant is there, what robber, or open violator of the laws of society, who has not a 30

sich von andern gelobt vorstellt. Denn je mehr er sich von andern gelobt vorstellt, um so stärker stellt er sich die Lust vor, von welcher andere durch ihn erregt werden. - Satz 55, Anm.: Die Lust, die aus der Betrachtung unserer selbst entspringt, heißt Selbstliebe oder Selbstzufriedenheit. 
companion, or some particular set, either of his own kindred, or such as he calls friends, with whom he gladly shares his good, in whose welfare he delights, and whose joy and satisfaction he makes his own? ; What person in the world is there who receives not some impressions from the flattery or kindness of such as are familiar with him? 'Tis to this soothing hope and expectation of friendship that almost all our actions have some reference. 'Tis this ro which goes through our whole lives, and mixes itself even with most of our vices. Of this, vanity, ambition, and luxury have a share, and many other disorders of our life partake. So that were pleasure to be computed in the same way as other things comis monly are, it might properly be said, that out of these two branches (viz. community or participation in the pleasures of others, and belief of meriting well from others) would arise more than nine-tenths of whatever is enjoyed in life. And thus in the main sum of hap${ }^{20}$ piness there is scarce a single article ${ }^{1}$ but what derives itself from social love, and depends immediately on the natural and kind affections.

Now such as causes are, such must be their effects. And therefore as natural affection or 2 social love is perfect or imperfect, so must be the content and happiness depending on it.

It will be acknowledged that a creature such as man, who from several degrees of reflection ${ }^{2}$ has risen to that capacity which we call reason and understanding, $3^{\circ}$ must in the very use of this his reasoning faculty be

1 a single article "ein cinzelnes Glied", ein einzelner Posten in der Gesamtsumme; v. gr. arthrŏn Glied.

2 from several degrees of reflection ... " "durch verschiedene Stufen der Denktätigkeit hindurch ..... 
forced to receive reflections back into his mind ${ }^{1}$ of what passes in itself, as well as in the affections or will; in short of whatsoever relates to his character, conduct, or behaviour amidst his fellow-creatures and in society. Or should he be of himself unapt, there are others s ready to remind him, and refresh his memory in this way of criticism ${ }^{2}$. We have all of us remembrancers enow $^{3}$ to help us in this work. Nor are the greatest favourites of Fortuna exempted from this task of selfinspection. Even flattery itself, by making the view to agreeable, renders us more attentive this way, and ensnares us $^{4}$ in the habit. The vainer any person is, the more he has his eye inwardly fixed upon himself, and is after a certain manner employed in this home survey. And when a true regard to ourselves cannot oblige is us to this inspection, a false regard to others and a fondness for reputation raises a watchful jealousy, and furnishes us sufficiently with acts of reflection on our own character and conduct.

In whatever manner we consider of this, we shall 20 find still, that every reasoning or reflecting creature is by his nature forced to endure the review of his own mind and actions, and to have representations of himself and his inward affairs constantly passing before him, obvious to him, and revolving in 25 his mind. Now as nothing can be more grievous than this is to one who has thrown off natural affection, so

1 to receive reflections back into his mind «in seinen Geist Bilder, Vorstellungen zurückzuempfangen».

2 criticism «Kritik, Prüfung». Das gr. kritikê, die Kunst des Unterscheidens und Beurteilens; kritikós urspr. der Name des Philologen, der die Schönheiten und Mängel der Dichtungen aussondert, also ästhetische Kritik übt.

3 enow s. v. a. enough.

4 ensnares us "verstrickt uns». Vgl. S. 30, Anm. I. 
nothing can be more delightful to one who has preserved it with sincerity. ${ }^{1}$

There are two things which to a rational creature must be horridly offensive and grievous, viz. to have s the reflection in his mind of any unjust action or behaviour which he knows to be naturally odious and ill-deserving; or of any foolish action or behaviour which he knows to be prejudicial to his own interest or happiness.

10 The former of these is alone properly called Conscience $^{2}$, whether in a moral or religious sense. For to have awe and terror of the Deity does not, of itself, imply conscience. No one is esteemed the more conscientious for the fear of evil spirits, conjurations, is enchantments, or whatever may proceed from any unjust, capricious, or devilish nature ${ }^{3}$. Nor to fear God any otherwise than as in consequence of some justly blamable and imputable act, is to fear a devilish nature, not a divine one. Nor does the fear of hell or a 20 thousand terrors of the Deity imply conscience, unless where there is an apprehension of what is wrong, odious, morally deformed, and ill-deserving. And where this is the case, there conscience must have effect, and punishment of necessity be apprehended ${ }^{4}$, even though 25 it be not expressly threatened.

And thus religious conscience supposes

1 Diese mit Kritik gepaarte, Billigung oder Milbilligung enthaltende Vorstellung unserer Gedanken und Handlungen ist das "Gewissen"; das "Bewußtsein» der guten oder bösen Tat äußert sich in "guten» oder "bösen" Gewissen.

2 conscience, con-scientia, aus dem gr. syn-eidēsis übersetzt, umfaßt ursprünglich die beiden Begriffe "Bewußtsein») (consciousness) und "Gewissen".

s devilish nalure "teuflisches Wesen".

4 apprebended "befürchtet, erwartet); apprehension geistiges Erfassen, Vorstellung, Erwartung, Besorgnis, Argwohn. 
moral or natural conscience. And though the former be understood to carry with it the fear of divine punishment, it has its force however from the apprehended moral deformity and odiousness of any act with respect purely of the Divine Presence, and the natural s veneration due to such a supposed being. For in such a presence the shame of villany or vice must have its force, independently on that further apprehension of the magisterial capacity ${ }^{1}$ of such a being, and his dispensation of particular rewards or punishments in to a future state.

It has been already said, that no creature can maliciously and intentionally do ill without being sensible at the same time that he deserves ill. And in this respect, every sensible creature may be said to have conscience. is For with all mankind, and all intelligent creatures, this must ever hold, that what they know they deserve from every one, that they necessarily must fear and expect from all. And thus suspicions and ill apprehensions must arise, with terror both of men and 20 of the Deity. But besides this, there must in every rational creature be yet farther conscience, viz. from sense of deformity ${ }^{2}$ in what is thus ill-deserving and unnatural, and from a consequent shame or regret of incurring what is odious and moves aversion.

Nor, as for that other part of conscience, viz. the remembrance of what was at any time unreasonably and foolishly done in prejudice of one's real interest or happiness; this dissatisfactory reflection must follow still and have effect, wheresoever there is a sense of 30 moral deformity contracted by crime and injustice. For even where there is no sense of moral deformity as

1 magisterial capacity "Herrschergewalt».

2 sense of deformity "Gefühl für die Häßlichkeit», wie bei guten Handlungen Gefühl für die Schönheit. 
such merely, there must be still a sense of the ill merit of it with respect to God and man. Or though there were a possibility of excluding for ever all thoughts or suspicions of any superior powers, yet considering that $s$ this insensibility towards moral good or ill implies a total defect in natural affection, and that this defect can by no dissimulation be concealed, 'tis evident that a man of this unhappy character must suffer a very sensible loss in the friendship, trust, and confidence of so other men, and consequently must suffer in his interest and outward happiness. Nor can the sense of this disadvantage fail to occur to him, when he sees, with regret and envy, the better and more grateful terms of friendship and esteem on which better people live with is the rest of mankind. Even therefore where natural affection is wanting, 'tis certain still, that by immorality, necessarily happening through want of such affection, there must be disturbance from conscience of this sort, viz. from sense of what is committed impru20 dently and contrary to real interest and advantage.

From all this we may easily conclude how much our happiness depends on natural and good affection. For if the chief happiness be from the mental pleasures, and the chief mental pleasures are 25 such as we have described, and are founded in natural affection, it follows that to have the natural affections is to have the chief means and power of self-enjoyment, the highest possession and happiness of life.

3o But ere we conclude this article of social or natural affection we may take a general view of it, and bring it once for all into the scale ${ }^{1}$, to prove what kind of balance it helps to make within, and what the consequence may be of its deficiency or light weight.

1 scale "Wagschale" oder Wage (gew. scales). 
There is no one of ever so little understanding in what belongs to a human constitution who knows not that without action, motion, and employment the body languishes and is oppressed; its nourishment turns to disease; the spirits, unemployed abroad, help to con- s sume the parts within; and Nature, as it were, preys upon herself ${ }^{1}$. In the same manner, the sensible and living part, the soul or mind, wanting its proper and natural exercise, is burdened and diseased. Its thoughts and passions being unnaturally withheld from their due ro objects, turn against itself, and create the highest impatience and ill-bumour.

In brutes and other creatures who have not the use of reason and reflection (at least not after the manner of mankind) 'tis so ordered in Nature that by is their daily search after food, and their application either towards the business of their livelihood ${ }^{2}$ or the affair of their species or kind, almost their whole time is taken up, and they fail not to find full employment for their passion according to that degree of agitation 20 to which they are fitted, and which their constitution requires. If any one of these creatures be taken out of his natural laborious state and placed amidst such a plenty as can profusely administer to all his appetites and wants, it may be observed that as his cir- 25 cumstances grow thus luxuriant, his temper and passions have the same growth. When he comes at any time to have the accommodations of life at a cheaper and easier rate than was at first intended him by $\mathrm{Na}$ ture, he is made to pay dear for them in an-30 other way, by losing his natural good disposition and the orderliness of his kind or species.

1 preys upon berself "verzehrt sich selbst).

2 livelihood "Lebensunterhalt, Lebensbedürfnisse». 
This needs not to be demonstrated by particular instances. Whoever has the least knowledge of $\mathrm{Na}$ tural History, or has been an observer of the several breeds of creatures, and their ways of life and propa$s$ gation, will easily understand this difference of orderliness between the wild and the tame of the same species. The latter acquire new habits, and deviate from their original nature. They lose ever the common instinct and ordinary ingenuity of their kind, nor can to they ever regain it whilst they continue in this pampered $^{1}$ state; but being turned to shift abroad, they resume the natural affection and sagacity of their species. They learn to unite in stricter fellowship, and grow more concerned for their offspring. They provide 15 against the seasons, and make the most of every advantage given by Nature for the support and maintenance of their particular species against such as are foreign and hostile. And thus as they grow busy and employed, they grow regular and good. Their petulancy ${ }^{2}$ and 20 vice forsakes them with their idleness and ease.

It happens with mankind that whilst some are by necessity confined to labour, others are provided with abundance of all things by the pains and labour of inferiors. Now, if among the superior and easy ${ }_{25}$ sort there be not something of fit and proper employment raised in the room of what is wanting in common labour and toil; if instead of an application to any sort of work, such as has a good and honest end in society (as letters, sciences, arts, husbandry ${ }^{3}$, ${ }^{30}$ public affairs, economy, or the like), there be a tho-

1 pampered "üppig».

2 betulancy "Übermut, Frechheit».

s husbandry "Landwirtschaft", während economy hier nicht im Sinne von "Ökonomie" zu nehmen ist, sondern political economy, Staatswissenschaften bedeutet. 
rough neglect of all duty or employment; a settled idleness, supineness ${ }^{1}$, and inactivity; this of necessity must occasion a most relaxed and dissolute state: it must produce a total disorder of the passions, and break out in the strangest irregularities imaginable.

We see the enormous growth of luxury in capital cities, such as have been long the seat of empire. We see what improvements are made in vice of every kind where numbers of men are maintained in lazy opulence and wanton plenty. 'Tis otherwise with those who ro are taken up in honest and due employment, and have been well inured to it from their youth. This we may observe in the hardy remote provincials, the inhabitants of smaller towns, and the industrious sort of common people, where 'tis rare to meet with any instances' of is those irregularities which are known in courts and palaces, and in the rich foundations ${ }^{2}$ of easy and pampered priests.

Now if what we have advanced concerning an inward constitution be real and just; if it be true that 20 Nature works by a just order and regulation as well in the passions and affections as in the limbs and organs which she forms; if it appears withal that she has so constituted this inward part that nothing is so essential to it as exercise, and no exercise so essential as 25 that of social or natural affection; it follows that where this is removed or weakened, the inward part must necessarily suffer and be impaired. Let indolence, indifference, or insensibility be studied as an art, or cultivated with the utmost care, 30 the passions thus restrained will force their prison, and

1 supineness «Faulenzerei»; von supine "auf dem Rücken liegend).

2 foundations "Stiftungen». 
in one way or other procure their liberty and find full employment. They will be sure to create to themselves unusual and unnatural exercise where they are cut off from such as is natural and good. And thus $s$ in the room of orderly and natural affection, new and unnatural must be raised, and all inward order and economy destroyed.

One must have a very imperfect idea of the order of Nature in the formation and structure of animals to so imagine that so great a principle, so fundamental a part as that of natural affection, should possibly be lost or impaired, without any inward ruin or subversion of the temper and frame of mind.

Whoever is the least versed in this moral kind of is architecture ${ }^{1}$, will find the inward fabric ${ }^{2}$ so adjusted, and the whole so nicely built, that the barely extending of a single passion a little too far, or the continuance of it too long, is able to bring irrecoverable ruin and misery. He will find this experienced in the 20 ordinary case of frenzy and distraction ${ }^{3}$, when the mind, dwelling too long upon one subject (whether prosperous or calamitous) sinks under the weight of it, and proves what the necessity is of a due balance and counterpoise in the affections. He will find that in every different as creature and distinct sex there is a different and distinct order, set, or suit of passions, proportionable to the different order of life, the different functions and capacities assigned to each. As the operations and effects are different, so are the springs and causes in

1 in this moral kind of arclitecture "in dieser die Sitten betreffenden Art Baukunst).

2 inward fabric, weiter unten inside work, "innerer Bau, inneres Uhrwerk").

${ }^{3}$ frenzy and distraction "Narrheit und Raserei»: frenzy v. gr. phrénẽsis, s. v. a. phrenftis, Gehirnentzündung u. dgl. 
each system. The inside work is fitted to the outward action and performance. So that where habits or affections are dislodged, misplaced, or changed, where those belonging to one species are intermixed with those belonging to another, there must of neces- , sity be confusion and disturbance within.

The ordinary animals appear unnatural and monstrous when they lose their proper instincts, forsake their kind, neglect their offspring, and pervert those functions or capacities bestowed by Nature. How wret- so ched must it be, therefore, for man, of all other creatures, to lose that sense and feeling which is proper to him as a man, and suitable to his character and genius? How unfortunate must it be for a creature whose dependence on society is grea-is ter than any others, to lose that natural affection by which he is prompted to the good and interest of his species and community? Such indeed is man's natural share of this affection, that he, of all other creatures, is plainly the least able 20 to bear solitude. Nor is anything more apparent than that there is naturally in every man such a degree of social affection as inclines him to seek the familarity and friendship of his fellows. 'Tis here that he lets loose a passion, and gives reins to a desire which can 2 ; hardly by any struggle or inward violence be withheld; or if it be, is sure to create a sadness, dejection, and melancholy in the mind. For whoever is unsociable, and voluntarily shuns society or commerce with the world, must of necessity be morose and ill-natured. $3 \circ$ $\mathrm{He}$, on the other side, who is withheld by force or accident, finds in his temper the ill effects of this restraint. The inclination, when suppressed, breeds discontent, and on the contrary affords a heading and enlivening joy when acting at its liberty and with full 35 
scope $^{1}$; as we may see particularly when after a time of solitude and long absence the heart is opened, the mind disburdened, and the secrets of the breast unfolded to a bosom friend.

s Thus it may appear how much natural affection is predominant: how it is inwardly joined to us, and implanted in our natures; how interwoven with our other passions, and how essential to that regular motion and course of our affections on which our happiness and ro self-enjoyment so immediately depend.

And thus we have demonstrated that as, on one side, to have the natural and good affections is to have the chief means and power of self-enjoyment; so, on the other side, to want them is certain misery and ill.

\section{Section II.}

We are now to prove, that by having the selfpassions too intense or strong, a creature becomes miserable.

If there were any of these self-passions which for 20 the good and happiness of the creature might be opposed to natural affection, and allowed to over-balance it, the desire and love of life would have the best pretence. But it will be found perhaps that there is no passion which, by having much allowed to it, is the 25 occasion of more disorder and misery.

There is nothing more certain or more universally agreed than this, that life may sometimes be even a misfortune and misery. To enforce the continuance of it in creatures reduced to such extremity is esteemed so the greatest cruelty. And though religion forbids that any one should be his own reliever, yet if by some

1 scope v. gr. skopós, eig. Späher, Wächter, dann Ziel, Zweck; with full scope "mit freiem Spielraum". 
fortunate accident, death offers of itself, it is embraced as highly welcome. And on this account the nearest friends and relations often rejoice at the release of one entirely beloved, even though he himself may have been so weak as earnestly to decline death, and s endeavour the utmost prolongment of his own uneligible ${ }^{1}$ state.

Since life, therefore, may frequently prove a misfortune and misery, and since it naturally becomes so by being only prolonged to the infirmities of old age; ro since there is nothing, withal, more common than to see life over-valued, and purchased at such a cost as it can never justly be thought worth, it follows evidently that the passion itself (viz. the love of life, and abhorrence or dread of death) if beyond a certain is degree, and over-balancing in the temper of any creature, must lead him directly against his own interest; make him, upon occasion, become the greatest enemy to himself, and necessitate him to act as such.

There is another passion ${ }^{2}$ very different from that 20 of fear and which in a certain degree is equally preservative to us, and conducing to our safety. As that is serviceable in prompting us to shun ${ }^{3}$ danger, so is this in fortifying us against it, and enabling us to repel injury and resist violence when offered. 'Tis 25 true, that according to strict virtue, and a just regulation of the affections, in a wise and virtuous man, such efforts towards action amount not to what is justly styled passion or commotion. A man of courage may be cautious without real fear; and a man of $3^{\circ}$

1 uneligible: was man sich nicht auswählen würde, also etwa «beklagenswert, jammervoll».

2 nämlich anger, im weitesten Sinn: Unwillen, Ärger, Zorn, Wut u. s. w.

3 to shun "scheuen, vermeiden». 
temper may resist or punish without anger, but in ordinary characters there must necessarily be some mixture of the real passions themselves, which, however, in the main, are able to allay and temper one another. s And thus anger in a manner becomes necessary. 'Tis by this passion that one creature offering violence to another is deterred from the execution, whilst he observes how the attempt affects his fellow, and knows by the very signs which accompany this so rising motion, that if the injury be carried further, it will not pass easily on with impunity. It is this passion withal which, after violence and hostility executed, rouses a creature in opposition, and assists him in returning like hostility and harm on the inis vader. For thus, as rage and despair increase, a creature grows still more terrible, and being urged to the greatest extremity, finds a degree of strength and boldness unexperienced till then, and which had never risen except through the height of provocation. As 20 to this affection therefore, notwithstanding its immediate aim be indeed the ill or punishment of another, yet it is plainly of the sort of those, which tend to the advantage and the interest of the self-system, the animal himself, and is withal in other respects contri25 buting to the good and interest of the species. But there is hardly need we should explain how mischievous and self-destructive anger is, if it be what we commonly understand by that word: if it be such a passion as is rash and violent in the instant of pro3o vocation, or such as imprints itself deeply, and causes a settled revenge and an eager vindicative pursuit.

Now as to luxury and what the world calls pleasure: were it true that the most considerable enjoyments were those merely of the sense; and were it true, 3s withal, that those enjoyments of the sense lay in cer- 
tain outward things capable of yielding always a due and certain portion of pleasure, according to their degree and quality, it would then follow that the certain way to obtain happiness would be to procure largely of these subjects to which happiness and pleasure were s thus infallibly annexed. But however fashionably we may apply the notion of good living, 'twill hardly be found that our inward faculties are able to keep pace with these outward supplies of a luxuriant fortune. And if the natural disposition and aptness from within be ro not concurring, 'twill be in vain that these subjects are thus multiplied from abroad, and acquired with ever so great facility.

It may be observed in those who by excess have gained a constant nauseating ${ }^{1}$ and distaste, that they have ${ }^{\prime} ;$ nevertheless as constant a craving ${ }^{2}$ or eagerness of stomach. But the appetite of this kind is false and unnatural, as is that of thirst arising from a fever, or contracted by habitual debauch. Now the satisfactions of the natural appetite, in a plain way, are infinitely beyond those 20 indulgences of the most refined and elegant luxury. This is often perceived by the luxurious themselves. It has been experienced in people bred after the sumptuous way, and used never to wait, but to prevent appetite, that when by any new turn of life they came ${ }^{25}$ to fall into a more natural course, or for a while, as on a journey, or a day of sport, came accidentally to experience the sweet of a plain $\operatorname{diet}^{3}$, recommended by due abstinence and exercise, they have with freedom

1 nauseating (Ekel, Brechreiz); geht zurück auf lat. nausea, die See-, genauer Schiffskrankheit.

2 a craving ein Verlangen, eine "Gier».

3 plain diet "einfache Kost»; vom gr. diaita "Lebensunterhalt, Nahrung", insbesondere die vom Arzt vorgeschriebene Krankenkost. 
owned that if was then they received the highest satisfaction and delight which a table could possibly afford.

On the other side, it has been as often remarked in persons accustomed to an active life and healthful s exercise, that having once thoroughly experienced this plainer and more natural diet, they have upon a following change of life regretted their loss, and undervalued $^{1}$ the pleasures received from all the delicacies of luxury in comparison with those remembered satisto factions of a preceding state. 'Tis plain that by urging Nature, forcing the appetite, and inciting sense, the keenness $^{2}$ of the natural sensations is lost. And though through vice or ill habit, the same subjects of appetite may every day be sought with less satisfaction; though is the impatience of abstaining be greater, the pleasure of indulgence is really less; the palls ${ }^{3}$ or nauseatings which continually intervene are of the worst and most hateful kind of sensation. Hardly is there anything tasted which is wholly free from this ill relish of a surfeited .20 sense and ruined appetite. So that instead of a constant and flowing delight afforded in such a state of life, the very state itself is in reality a sickness and infirmity, a corruption of pleasure, and destructive of every natural and agreeable sensation. So far is it from being 25 true that in this licentious course we enjoy life best, or are likely to make the most of it.

As to the consequences of such an indulgence: how fatal to the body, by diseases of many kinds, and to the mind, by sottishness and stupidity; this needs not 30 any explanation.

Now as to that passion which is esteemed peculiarly

1 undervalue hier "geringschätzen», nicht "unterschätzen».

2 keenness "Schärfe, Heftigkeit, Stärke».

3 pall "Übelkeit". 
interesting ${ }^{1}$, as having for its aim the possession of wealth, and what we call a settlement or fortune in the world: if the regard towards this kind be moderate and in a reasonable degree; if it occasions no passionate pursuit, nor raises any ardent desire or appetite; there is nothing s in this case which is not compatible with virtue, and even suitable and beneficial to society. The public as well as private system is advanced by the industry which this affection excites. But if it grows at length into a real passion, the injury and mischief it does the so public is not greater than that which it creates to the person himself. Such a one is in reality a self-oppressor, and lies heavier on himself than he can ever do on mankind.

How far a coveting ${ }^{2}$ or avaricious temper is is miserable, needs not surely be explained. Who knows not how small a portion of worldly matters is suffcient for a man's single use and convenience; and how much this occasions and wants might be contracted and reduced if a just frugality were studied, and temperance 20 and a natural life came once to be pursued with half that application, industry, and art which is bestowed on sumptuousness and luxury? Now if temperance be in reality so advantageous, and the practice as well as the consequences of it so pleasing and happy, as has 25 been before expressed, there is little need, on the other side, to mention anything of the miseries attending those covetous and eager desires after things which have no bounds or rule; as being out of Nature, beyond which there can be no limits to desire. For where shall we 30 once stop when we are beyond this boundary? How shall we fix or ascertain a thing wholly unnatural and unreasonable?

1 interesting "selbstsüchtig, eigennützig».

2 coveting, covetous (habsüchtig). 
Hence that known restlessness of covetous and eager minds in whatever state or degree of fortune they are placed; there being no thorough or real satisfaction, but a kind of insatiableness belonging to $s$ this condition. For 'tis impossible there should be any real enjoyment except in consequence of natural and just appetite. Nor do we readily call that an enjoyment of wealth or of honour when through covetousness or ambition the desire is still forward to and can never rest satisfied with its gains. But against this vice of covetousness there is enough said continually in the world.

Nor is there less said abroad as to the ills of that other aspiring temper, which exceeds an honest emuis lation or love of praise, and passes the bounds even of vanity and conceit ${ }^{1}$. Such is that passion which breaks into an enormous pride and ambition. Nor if we consider once the ease, happiness and security which attend a modest disposition and quiet mind, 20 such as is of easy self-command, fitted to every station in society, and able to suit itself with any reasonable circumstances whatever, 'twill on the first view present us with the most agreeable and winning character. Nor will it be found necessary after this to call to 25 mind the excellence and good of moderation, or the mischief and self-injury of immoderate desires, and conceited fond imagination of personal advantage, in such things as titles, honours, precedencies, fame, glory, or vulgar astonishment, admiration, and applause.

30 This too is obvious, that as the desires of this kind are raised and become impetuous, and out of our command, so the aversions and fears of the contrary part grow proportionally strong and violent, and

1 conceit, self-conceit "Einbildung, Dünkel». 
the temper accordingly suspicious, jealous, captious, subject to apprehensions from all events, and incapable of bearing the least repulse or ordinary disappointment. And hence it may be concluded that all rest and security as to what is future, and all peace, contented- s ness, and ease as to what is present, is forfeited by the aspiring passions of this emulous kind; and by having the appetites towards glory and outward appearance thus transporting and beyond command.

There is a certain temper placed often in opposi- ro tion to those eager and aspiring aims of which we have been speaking. Not that it really excludes either the passion of covetousness or ambition, but because it hinders their effects, and keeps them from breaking into open action. 'Tis this passion which by soothing is the mind and softening it into an excessive love of rest and indolence, renders high attempts impracticable, and represents as insuperable the difficulties of a painful and laborious course towards wealth and honours. Now though an inclination to ease, and a 20 love of moderate recess and rest from action, be as natural and useful to us as the inclination we have towards sleep, yet an excessive love of rest, and a contracted aversion to action and employment, must be a disease in the mind equal to that of a lethargy ${ }^{1}$ 25 in the body.

How necessary action and exercise are to the body may be judged by the difference we find between those constitutions which are accustomed, and those which are wholly strangers to it; and by the different health 30 and complexion which labour and due exercise create, in comparison with that habit of body we see consequent to an indulged state of indolence and rest. Nor

1 lethargy "Schlafsucht»; v. gr. lēthē, Vergessen. 
is the lazy habit ruinous to the body only. The languishing disease corrupts all the enjoyments of a vigorous and healthy sense, and carries its infection into the mind, where it spreads a worse contagion. s For however the body may for awhile hold out, 'tis impossible that the mind, in which the distemper is seated, can escape without an immediate affliction and disorder. The habit begets a tediousness and anxiety, which influences the whole temper, and converts the to unnatural rest into an unhappy sort of activity, illhumour, and spleen ${ }^{1}$, of which there has been enough said above, where we considered the want of a due balance in the affections.

'Tis certain that as in the body, when no labour is or natural exercise is used, the spirits ${ }^{2}$ which want their due employment turn against the constitution, and find work for themselves in a destructive way; so in a soul or mind unexercised, and which languishes for want of proper action and employment, the 20 thoughts and affections being obstructed in their due course, and deprived of their natural energy, raise disquiet, and foment a rancorous eagerness and tormenting irritation. The temper from hence becomes more impotent in passion, more incapable of real moderation, ${ }^{25}$ and, like prepared fuel ${ }^{3}$, readily takes fire by the least spark. - And thus 'tis evident that to have this overbiassing ${ }^{4}$ inclination towards rest, this slothful, soft,

1 spleen v. gr. splēn (Milz), die bekannte, aus Mangel an vernünftiger Beschäftigung und Übersättigung mit Vergnügen entstehende, besonders in den wohlhabenden Ständen Englands verbreitete Hypochondrie.

2 the spirits "die Lebensgeister"; ein bis auf Galen und Aristoteles zurückgehender Versuch, die Lebensvorgänge zu erklären.

3 like prepared fuel etwa: "wie dürres Reisig»; fuel «Brennmaterial) (aus focus, focale).

4 overbiassing "übermäßig", von bias, Hang, Neigung. 
or effeminate temper, averse to labour and employment, is to have an unavoidable mischief and attendant plague.

Thus have we considered the self-passions, and what the consequence is of their rising beyond a mo- s derate degree. These affections, as self-interesting as they are, can often, we see, become contrary to our real interest. They betray us into most misfortunes and into the greatest of unhappinesses, that of a profligate and abject character. As they grow imperious so and high, they are the occasion that a creature in proportion becomes mean and low. They are original to that which we call selfishness, and give rise to that sordid disposition of which we have already spoken. It appears there can be nothing so miserable in itself, is or so wretched in its consequence, as to be thus impotent in temper, thus mastered by passion, and by means of it brought under the most servile subjection to the world.

'Tis evident, withal, that as this selfishness increases 20 in us, so must a certain subtlety and feignedness of carriage which naturally accompanies it. And thus the candour and ingenuity of our natures, the ease and freedom of our minds, must be forfeited, all trust and confidence in a manner lost, and 25 suspicions, jealousies, and envies multiplied. A separate end and interest must be every day more strongly formed in us; generous views and motives laid aside; and the more we are thus sensibly disjoined every day from society and our fellows, the worse opinion 30 we shall have of those uniting passions which bind us in strict alliance and amity with others. Upon these terms we must of course endeavour to silence and suppress our natural and good affections, since they are such as would carry us to the good of society 35 
against what we fondly conceive to be our private good and interest, as has been shown.

Now if these selfish passions, besides what other ill they are the occasion of, are withal the certain s means of losing us our natural affections; then (by what has been proved before) 'tis evident that they must be the certain means of losing us the chief enjoyment of life, and raising in us those horrid and unnatural passions, and that savageness of temper, ro which makes the greatest of miseries and the most wretched state of life, as remains for us to explain.

\section{Section III.}

The passions, therefore, which in the last place we are to examine, are those which lead neither to a pubis lic nor a private good, and are neither of any advantage to the species in general nor the creature in particular. These, in opposition to the social and natural, we call the unnatural affections.

Of this kind is that unnatural and inhuman 20 delight in beholding torments, and in viewing distress, calamity, blood, massacre and destruction, with a peculiar joy and pleasure. This has been the reigning passion of many tyrants and barbarous nations, and belongs in some degree to such tempers as have thrown 25 off that courteousness of behaviour which retains in us a just reverence of mankind, and prevents the growth of harshness and brutality. This passion enters not where civility ${ }^{1}$ has the least place. Such is the nature of what we call good breeding ${ }^{2}$, that in the midst of 30 many other corruptions it admits not of inhumanity

1 civility "Civilisation", Gegensatz barbarism. Ob Shaftesbury dem, was man gewöhnlich so nennt, nicht eine zu große Wirkung zuschreibt?

${ }^{2}$ good, ill breeding, gute, schlechte Erziehung, Lebensart. 
or savage pleasure. To see the sufferance of an enemy with cruel delight may proceed from the height of anger, revenge, fear, and other extended self-passions; but to delight in the torture and pain of other creatures indifferently, natives or foreigners, of our own s or another species, kindred or no kindred, known or unknown; to feed ${ }^{1}$ as it were on death, and be entertained with dying agonies; this has nothing in it accountable in the way of self-interest or private good above mentioned, but is wholly and absolutely unnatural, ro as it is horrid and miserable.

Malice, malignity or ill-will, such as is grounded on no self-consideration, and where there is no subject of anger or jealousy, nor anything to provoke or cause such a desire of doing ill to another, this also is of is that kind of passion.

Envy too, when it is such as arises from the prosperity or happiness of another creature no ways interfering with ours, is of the same kind of passion.

There is also among these a sort of hatred of man- 20 kind and society, a passion which has been known perfectly reigning in some men, and has had a peculiar name $^{2}$ given to it. A large share of this belongs to those who have long indulged themselves in a habitual moroseness, or who by force of ill-nature and ill-breed- 25 ing have contracted such a reverse of affability and civil manners that to see or meet a stranger is offensive. The very aspect of mankind is a disturbance to them, and they are sure always to hate at first sight. The distemper ${ }^{3}$ of this kind is sometimes found to be 30 in a manner national, but peculiar to the more savage

\footnotetext{
1 to feed "sich weiden".

2 misanthropy “Menschenha(b), v. gr. miseín hassen und án-

3 Vgl. oben Anm. 3, S. I8; v. gr. dyskrasía.
} thrōpos Mensch. 
nations, and a plain characteristic of uncivilised manners and barbarity. This is the immediate opposite to that noble affection which in ancient language was termed hospitality, viz. extensive love of mankind and relief $s$ of strangers.

We may add likewise to the number of the unnatural passions all those which are raised from $s u$ perstition (as before mentioned) and from the customs of barbarous countries; all which are too horrid and odious so in themselves to need any proof of their being miserable.

It may be objected here that these passions, unnatural as they are, carry still a sort of pleasure with them, and that however barbarous a pleasure it be, yet still it is a pleasure and satisfaction which is found in ss pride, or tyranny, revenge, malice, or cruelty exerted. Now if it be possible in Nature that any one can feel a barbarous or malicious joy otherwise than in consequence of mere anguish and torment, then may we perhaps allow this kind of satisfaction to be called plea2o sure or delight. But the case is evidently contrary. To love, and to be kind; to have social or natural affection, complacency, and good-will, is to feel immediate satisfaction and genuine content. 'T is in itself original joy, depending on no preceding 25 pain or uneasiness, and producing nothing beside satisfaction merely. On the other side, animosity, hatred, and bitterness, is original misery and torment, producing no other pleasure or satisfaction than as the unnatural desire is for the instant satisfied 30 by something which appeases it. How strong soever this pleasure therefore may appear, it only the more implies the misery of that state which produces it.

The men of gentlest disposition and best of temsi pers have at some time or other been sufficiently ac- 
quainted with those disturbances which, at ill hours, even small occasions are apt to raise. From these slender experiences of harshness and ill-humour they fully know and will confess the ill moments which are passed when the temper is ever so little galled or s fretted $^{1}$. How must it fare, therefore, with those who hardly know any better hours in life, and who, for the greatest part of it, are agitated by a thorough active spleen, a close and settled malignity and rancour? How lively must be the sense of every thwarting and con- ro trolling accident? How great must be the shocks of disappointment, the stings of affront, and the agonies of a working antipathy, against the multiplied objects of offence? Nor can it be wondered at if, to persons thus agitated and oppressed, it seems a high delight is to appease and allay for the while those furious and rough motions, by an indulgence of their passion in mischief and revenge.

Now as to the consequences of this unnatural state in respect of interest and the common circumstances 20 of life; upon what terms a person who has in this manner lost all which we call Nature can be supposed to stand in respect of the society of mankind, this is easily conceived. What enjoyment or rest is there for one who is not conscious of the merited affection or 25 love, but, on the contrary, of the ill-will and hatred of every human soul? Wherever such a creature turns himself, whichever way he cast his eye, everything around must appear ghastly and horrid; everything hostile and, as it were, bent against a private and single 30 being, who is thus divided from everything, and at defiance and war with the rest of Nature.

1 galled or fretted (geärgert oder verstimmt"; to gall wund reiben, kratzen, to fret anfressen, benagen. 
'Tis thus, at last, that a mind becomes a wilderness, where all is laid waste, everything fair and goodly removed, and nothing extant beside what is savage and deformed. Now if banishment from one's country, $s$ removal to a foreign place, or anything which looks like solitude or desertion, be so heavy to endure, what must it be to feel this inward banishment, this real estrangement from human commerce, and to be after this manner in a desert, and in the horridest of solito tudes even when in the midst of society? What must it be to live in this disagreement with everything, this irreconcilableness and opposition to the order and government of the universe?

Hence it appears that the greatest of miseries is accompanies that state which is consequent to the loss of natural affection; and that to have those horrid, monstrous, and unnatural affections is to be miserable in the highest degree.

\section{Conclusion.}

Thus have we endeavoured to prove what was proposed in the beginning. And since in the common and known sense of vice and illness, no one can be vicious or ill except either:

I. By the deficiency or weakness of natural affec2 tions; or

2. by the violence of the selfish; or

3. by such as are plainly unnatural,

it must follow that, if each of these are pernicious and destructive to the creature, insomuch that his comso pletest state of misery is made from hence, to be wicked or vicious is to be miserable and unhappy. 
On the other side, the happiness and good of virtue has been proved from the contrary effect of other affections, such as are according to Nature and the economy of the species or kind. We have cast up all those particulars from whence the main sum or s general account of happiness is either augmented or diminished. And if there be no article exceptionable in this scheme of moral arithmetic ${ }^{1}$, the subject treated may be said to have an evidence as great as that which is found in numbers or mathematics. For ro let us carry scepticism ever so far, let us doubt, if we can, of everything about us, we cannot doubt of what passes within ourselves. ${ }^{2}$ Our passions and affections are known to us. They are certain, whatever the objects may be on which they are employed. Nor is is

1 moral arithmetic - früher moral architecture - Anklänge an Spinoza. Dieser hatte seiner Ethik nicht nur'äußerlich, durch Anlehnung an die Beweismethoden Euklids, mathematische Sicherheit $z u$ geb'en versucht, sondern vor allem eine natürliche Theorie der menschlichen Leidenschaften aufgestellt: «Die Gesetze und Regeln der Natur, nach welchen alles geschieht und Formen in Formen verwandelt werden, sind überall und immer die gleichen. Daher kann es auch nur eine Methode geben, nach welcher die Natur aller Dinge, welche es immer seien, erkannt wird, nämlich durch die allgemeinen Gesetze und Regeln der Natur. Es erfolgen darum die Affekte, wie Haß, Zorn, Neid, an sich betrachtet, aus derselben Notwendigkeit und Kraft der Natur, wie alles andere. Hiernach haben sie ihre bestimmten Ursachen, durch welche sie erkannt werden, und haben bestimmte Eigenschaften, die unseres Erkennens ebenso würdig sind, wie die Eigenschaften eines jeden anderen Dinges, an dessen bloßer Betrachtung wir uns erfreuen. Ich werde daher die Natur und die Kräfte der Affekte, und die Macht des Geistes über dieselben, nach derselben Methode behandeln, nach welcher ich in den vorigen Teilen Gott und den Geist behandelt habe, und die menschlichen Handlungen und Begierden geradeso betrachten, als handelte es sich um Linien, Flächen oder Körper») (Ethik III, Vorwort).

2 Der Grundgedanke von Descartes' Scepticismus.

R u ska, Anthony Eari of Shaftesbury. 
it of any concern to our argument how these exterior objects stand: whether they are realities or mere illusions; whether we wake or dream. For ill dreams will be equally disturbing; and a good dream (if life $s$ be nothing else) will be easily and happily passed. In this dream of life, therefore, our demonstrations have the same force; our balance and economy hold good, and our obligation to virtue is in every respect the same.

ro Upon the whole, there is not, I presume, the least degree of certainty wanting in what has been said concerning the preferableness of the mental pleasures to the sensual; and even of the sensual, accompanied with good affection, and under a temperate and right is use, to those which are no way restrained, nor supported by anything social or affectionate.

Nor is there less evidence in what has been said of the united structure and fabric of the mind, and of those passions which constitute the temper or soul, 20 and on which its happiness or misery so immediately depend. It has been shown that in this constitution the impairing of any one part must instantly tend to the disorder and ruin of other parts, and of the whole itself, through the necessary connection and balance of 25 the affections; that those very passions through which men are vicious are of themselves a torment and disease; and that whatsoever is done which is knowingly ill must be of ill consciousness; and in proportion as the act is ill must impair and corrupt social enjoyment, $3^{\circ}$ and destroy both the capacity of kind affection and the consciousness of meriting any such. So that neither can we participate thus in joy or happiness with others, nor receive satisfaction from the mutual kindness or imagined love of others, on which, however, the grea3 test of all our pleasures are founded. 
Thus the wisdom of what rules, and is first and chief in Nature, has made it to be according to the private interest and good of everyone to work towards the general good, which if a creature ceases to promote, he is actually so far wanting to himself, and s ceases to promote his own happiness and welfare. So that virtue, which of all excellencies and beauties is the chief and most amiable; that which is the prop and ornament of human affairs; which upholds communities, maintains union, friendship, and correspon- to dence amongst men; that by which countries, as well as private families, flourish and are happy, and for want of which everything comely, conspicuous, great, and worthy, must perish and go to ruin; that single quality, thus beneficial to all society, and to mankind is in general, is found equally a happiness and good to each creature in particular, and is that by which alone man can be happy, and without which he must be miserable.

And thus virtue is the good, and vice the 20 ill of everyone. 


\section{Verzeichnis der Worterklärungen und sachlichen Anmerkungen.}

Administration 24 .

admiration 48 .

affection 32.

anger 99 .

antagonist 20.

antipathy 47 .

apostatise $6 \mathrm{r}$.

apprehension 90 .

art 26.

article 88 .

atheist 17,66 .

Bacon 86.

balance 74 .

Bayle I 7 .

Cicero $16,17,18$.

cities $8 \mathrm{I}$.

civility 108.

colour 42.

conscience 90 .

controll $6 \mathrm{I}$.

criticism 89 .

Daemon 23.

Descartes 3I, I 33 .

design 22.

devil 25 .

diet ror. discernment 22.

discipline 59.

economy $23,30,78,94$.

ecstasy 37 .

elegant 68.

ensnare 30.

essential 58.

execrable 83 .

faith 24 .

fancy 23.

frenzy 96 .

frowardness 36 .

fuel ro6.

galaxy 30 .

Galen I8.

galled III.

general notions 36 .

government 23 .

hazard $7 \mathrm{I}$.

Hippokrates 18.

historian 28.

Hobbes 72.

honest I8.

Hume 25 .

husbandry 94 .

hypothesis 23 . 
idiot 39.

immodest 43.

inferior world 30 .

ingredient 43 .

interest $21,27$.

key 80.

Leibniz 21.

. lethargy ios.

lute 80.

lyre 80.

Mandeville 73 .

matter 18.

melancholy 28 .

misanthropy 109.

monster 28.

moral 17,18 .

- sense 46.

- arithmetic II3.

musical numbers 37 .

nauseating IOI.

nice 19.

overbiassing 106.

passion 68.

piety 59.

pirate 40.

plague 32.

planetary system $3 \mathrm{I}$.

practice 16.

principle $17,22,44$.

profligate 65 .

providence 24 . reflection $37,88,89$.

religion 15 .

scan 37.

scepticism 25 .

scheme 2.0 .

Schleiermacher 18.

scope 98 .

secular 76 .

Shaftesbury 16, 19, 21, 24, 26, 46, 51, 66, 68.

speculation 16 .

Spinoza 21, 26, 27, 49, 59, 86,

II 3 .

spirits 106.

spleen 106.

stress 65 .

styled 32 .

supineness 95 .

sympathy 47 .

system 29.

temper I8.

Toland 19.

uneligible 99 .

universe $2 \mathrm{I}$.

vagrant 38 .

verge 20 .

villain 45 .

virtue 15,16 .

vortex $3 \mathrm{I}$.

whole of things $2 \mathrm{I}$.

zeal 16. 


\section{Englische Schriftsteller aus dem Gebiete der Philosophie, Kulturgeschichte und Naturwissenschaft.}

\section{Ankündigung.}

Die Verlagsbuchhandlung beabsichtigt in Verbindung mit dem Unterzeichneten die Herausgabe einer Reihe von Werken englischer Schriftsteller aus dem Bereiche der Philosophie, Kulturgeschichte und Naturwissenschaft, wodurch dem immer mehr empfundenen Mangel an wirklich geistbildendem Lesestoff für die obersten Klassen unserer modern-sprachlichen Lehranstalten begegnet werden soll.

Während der Gymnasiast an einem bestimmit umschriebenen Kreis von Schriften unvergänglichen Wertes, durch Homer und die Tragiker, durch Herodot und Thukydides, durch Demosthenes und Platon den Geist des klassischen Altertums kennen lernt und im Neuen Testament sich ihm der Urquell unserer religiösen Überzeugungen erschließt, herrscht besonders in der Auswahl der französischen und englischen Prosalektüre trotz einiger neueren Versuche, eine Besserung herbeizuführen, noch immer die Mittelmäßigkeit und die Planlosigkeit. Die tieferen Gründe dieser Erscheinung zu untersuchen ist hier nicht der Ort; sie liegen zudem vielfach außerhalb des Machtbereichs der Schule. Über den Umfang und den Charakter der angekündigten Sammlung, die einen Beitrag zur Abhilfe leisten will und deren erster Band hiermit zur Ausgabe gelangt, mögen jedoch noch einige Worte gesagt werden.

Der Sinn für die Erörterung philosophischer, ethischer, religiöser, ästhetischer Probleme ist in unserer Zeit in erfreulichem Aufschwung begriffen. Wenn wir dessenungeachtet unsere Primaner ins Leben oder zur Universität entlassen, olıne in ihren empfänglichen und nach Klarheit und Wahrheit verlangenden Seelen das Interesse an den tiefsten Menschheitsfragen geweckt zu haben, so ist das eine Versündigung an der Jugend, die schwerer wiegt als jeder Ausfall an technischem Können oder gedächtnismäßigem Wissen.

Darum sollen in der Sammlung vor allem die Philosophen zu Worte kommen, in deren Schriften die leitenden Gedanken ihrer Zeit klassischen Ausdruck gefunden haben. Wenn hierbei nicht weiter als bis zu John Locke zurückgegriffen wurde, so geschal dies, weil keine Schrift sich so sehr wie Lockes "Essay concerning Human Understanding" zur Einführung in die spezifisch englische Philosophie und zur Vorbereitung auf die Lektüre eines modernen Philosophen eignet.

Als zweites Bändchen werden Teile von Shaftesburys "Characterislics" noch im Laufe des Sommers erscheinen; eine Auswahl aus David Humes philosophischen Schriften befindet sich in Vorbereitung. Sollte die Tendenz der Sammlung Beifall finden, so soll sie bis auf Herbert Spencer weitergeführt werden, in dessen Schriften der ganze Reichtum der modernen naturwissenschaft lichen Erkenntnis zu einem gewaltigen System ausgebaut ist.

Von Schriften kulturgeschichtlichen und naturwissenschaftlichen Inhalts sollen im allgemeinen nur solche aus dem letzten Jahrhundert Aufnahme finden. Es soll hier besonders darauf geachtet werden, wertvollen 
Inhalt in schöner Form darzubieten, auch sollen geeignete Autoren durch reichlichere Anmerkungen zur Lektüre in Sekunda eingerichtet werden.

In den für Prima bestimmten Bändchen beschränken sich die Anmerkungen auf das, was nicht jedes Lexikon bietet oder was auch dem Lehrer, der sich nicht lange Zeit mit dem behandelten Gegenstand beschäftigt hat, minder vertraut oder fremd zu sein pflegt. Es versteht sich von selbst, daß eine kurze Biographie des Autors und eine Übersicht seiner literarischen Leistungen vorausgeschickt werden.

Verlagsbuchhandlung und Herausgeber hoffen der Sache des modernen Schulwesens durch die Veranstaltung dieser neuen Sammlung einen Dienst zu erweisen und werden jede Anregung hinsichtlich der Erweiterung und Ausgestaltung des Planes dankbar entgegennehmen.

\section{Prof. Dr. Julius Ruska.}

Carl Winter's Universitätsbuchhandlung.

Erschienen sind:

I. Band.

Essay concerning Human Understanding

by John Locke.

Auswahl mit Anmerkungen von Prof. Dr. J. Ruska.

$8^{\circ}$. in Leinwand geb. I M. 6o Pf.

II. Band.

An Inquiry concerning Virtue or Merit by the Right Honourable Anthony Earl of Shaftesbury.

Mit Einleitung und Anmerkungen von Prof. Dr. J. Ruska.

$8^{\circ}$. in Leinwand geb. I M. 6o Pf.

III. Band.

Essays and Treatises on Several Subjects

by David Hume.

Auswahl mit Anmerkungen von Oberlehrer G. Budde.

$8^{\circ}$. in Leinwand geb. I M. 60 Pf.

IV. Band.

Nature and Causes of the Wealth of Nations

by Adam Smith.

Auswahl mit Anmerkungen von Prof. Dr. Andreas Voigt.

80. in Leinwand geb. I M. 6o Pf. (In Vorbereitung.)

V. Band.

First Principles of Synthetic Philosophy

by Herbert Spencer.

Auswahl mit Erläuterungen von Prof. Dr. J. Ruska.

$8^{\circ}$. in Leinwand geb. I M. 6o Pf. (In Vorbereitung.)

Weitere Bände werden folgen.

C. F. Winter'sche Buchdruckerei. 




\section{PLEASE DO NOT REMOVE CARDS OR SLIPS FROM THIS POCKET}

\section{UNIVERSITY OF TORONTO LIBRARY}

B

1386

I5

1904

Shaftesbury, Anthony Ashley Cooper, 3d earl of An inquiry concerning virtue or merit 


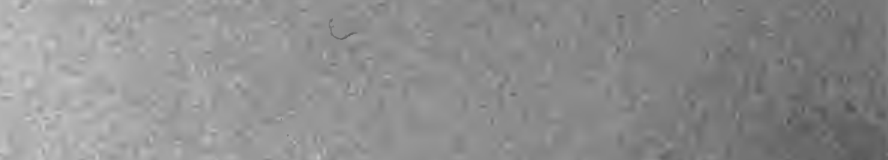

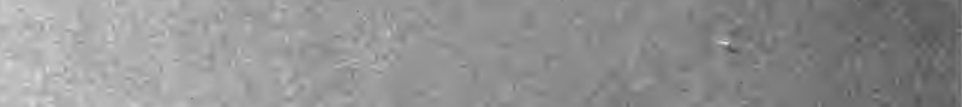

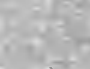

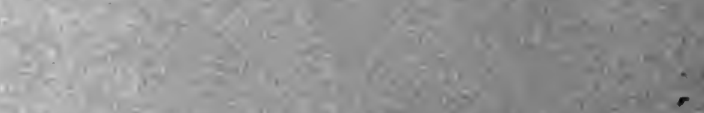

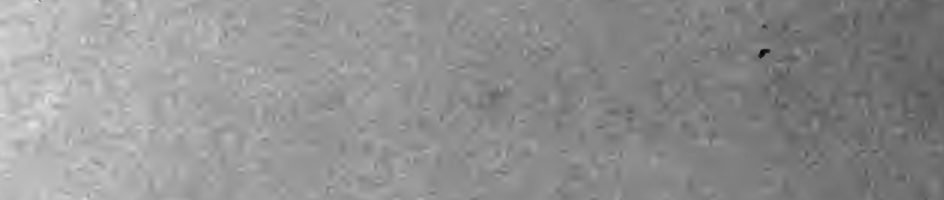

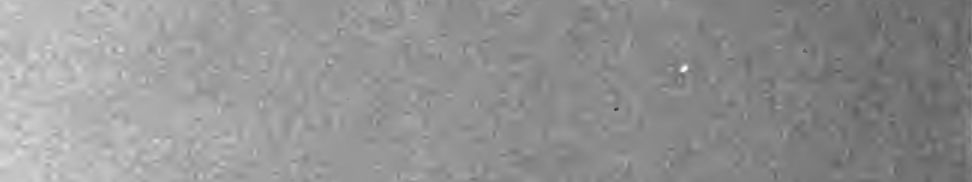

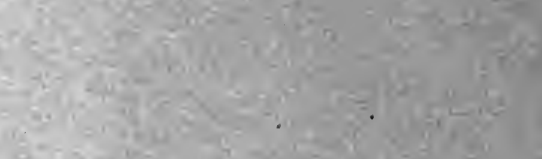

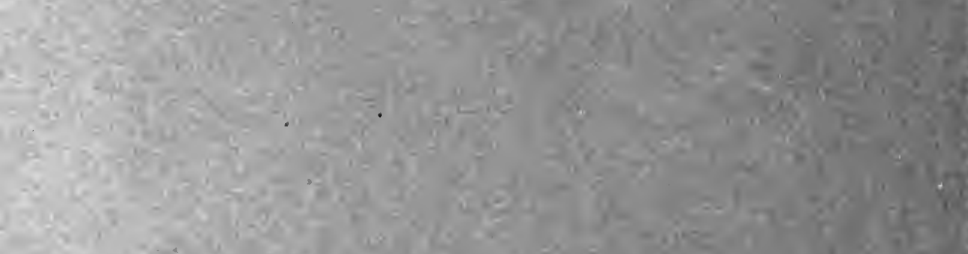
(2)

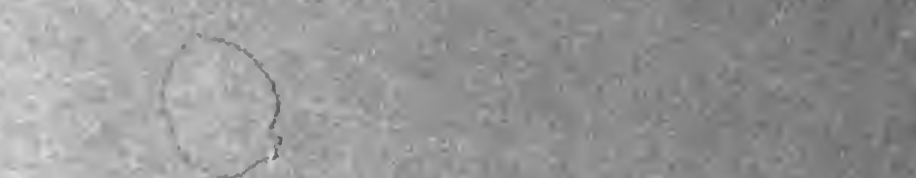

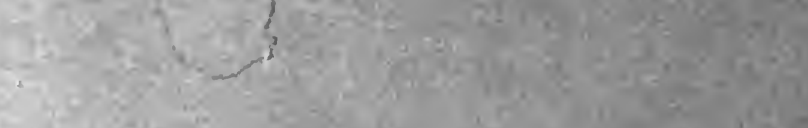

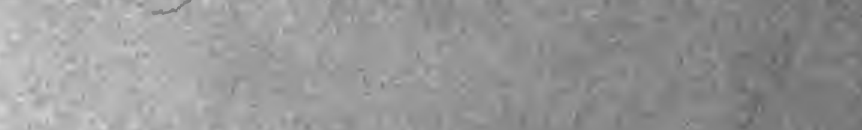

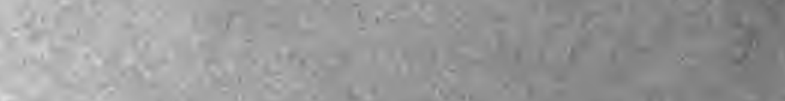
$\operatorname{sen}(x)$

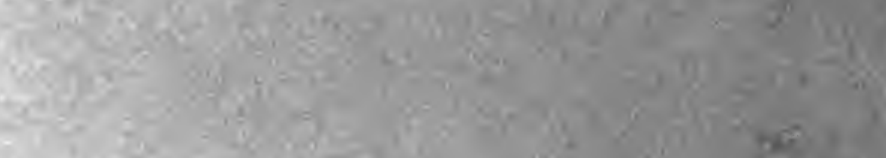

